\title{
The Effectiveness of Monetary Policy
}

\author{
Robert H. Rasche and Marcela M. Williams
}

\begin{abstract}
This analysis addresses changing views of the role and effectiveness of monetary policy, inflation targeting as an "effective monetary policy," monetary policy and short-run (output) stabilization, and problems in implementing a short-run stabilization policy. (JEL E520)
\end{abstract}

Federal Reserve Bank of St. Louis Review, September/October 2007, 89(5), pp. 447-89.

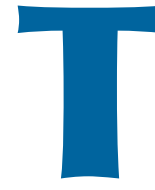
he effectiveness of monetary policy has been a long-standing question in the monetary economics and central banking literature. Perspectives on the question have been influenced in part by developments in monetary theory and in part by interpretations of monetary history. Progress in the discussion has also been influenced-indeed, some might say hindered-by changing definitions of both "monetary policy" and "effectiveness." Our discussion will address (i) changing views of the role and effectiveness of monetary policy, (ii) inflation targeting as an "effective monetary policy," (iii) monetary policy and shortrun (output) stabilization, and (iv) problems in implementing a short-run stabilization policy.

\section{CHANGING VIEWS ON THE ROLE AND EFFECTIVENESS OF MONETARY POLICY}

What do analysts mean by "monetary policy" and the "effectiveness" thereof? Each term is something of a moving target. At times "monetary policy" has referred to central bank actions to influence and/or target some measure of the money stock. Frequently, though certainly not always, the definition of monetary policy has focused on a measure of "high powered money"liabilities of the central bank. For a long time, this was the definition incorporated in theoretical models; in the policy arena this definition was the foundation of the "monetarist revolution" in the 1960s and 1970s. A counter definition that was likely the dominant perspective of policymakers was that monetary policy referred to central bank actions to influence and/or target short-term interest rates or nominal exchange rates. Sargent and Wallace (1975) advanced the proposition that, in a model with "rational expectations," the price level (and all other nominal variables) could be indeterminate if central banks set targets for nominal interest rates, because the economy would lack a "nominal anchor." McCallum (1981) showed that an appropriately defined interest rate rule would avoid such indeterminacy. The interest rate rule had to include a "nominal anchor." In recent years, in particular since Taylor's (1993) proposed characterization of Federal Open Market Committee (FOMC) behavior in the early Greenspan years, interest rate rules that include a "nominal anchor" in the form of a desired or target inflation rate have become the basic speci-

Robert H. Rasche is a senior vice president and director of research and Marcela M. Williams is a senior research associate at the Federal Reserve Bank of St. Louis. This article was originally presented at the Bank of Korea's conference, "The Effectiveness of Stabilization Policies," May 27, 2005, Seoul, Korea, and was published in their conference proceedings in 2006. The article is reprinted here with permission from the Bank of Korea.

(C) 2007, The Federal Reserve Bank of St. Louis. Articles may be reprinted, reproduced, published, distributed, displayed, and transmitted in their entirety if copyright notice, author name(s), and full citation are included. Abstracts, synopses, and other derivative works may be made only with prior written permission of the Federal Reserve Bank of St. Louis. 
fication of "monetary policy" in theoretical analyses. (See, for example, Clarida, Galí, and Gertler, 1999.)

The legacy of the Great Depression in the United States and other industrialized economies was that monetary policy was "ineffective." This perspective is most prominent in Keynes's General Theory and in the writings of the "Keynesian economists" in the 1940s through the 1960s. For example, the Radcliffe Committee in the United Kingdom reported that

[t]he immediate object of monetary policy action is to affect the level of total demand... In theory, monetary action may work upon total demand by changing the interest incentive; we believe that only very limited reliance can be placed on this. More certainly, monetary action works upon total demand by altering the liquidity position of financial institutions and of firms and people desiring to spend on real resources; the supply of money itself is not the critical factor. (Radcliffe, 1959, p. 135)

In the United States the minimalist perspective on the role and effectiveness of monetary policy can be seen in the first two reports of the Kennedy Council of Economic Advisers:

Unless the Government acts to make compensating changes in the monetary base, expansion of general economic activity, accompanied by increased demands for liquid balances and for investment funds will tend to tighten interest rates and restrict the availability of credit... Discretionary policy is essential, sometimes to reinforce, sometimes to mitigate or overcome, the monetary consequences of short-run fluctuations of economic activity. In addition, discretionary policy must provide the base for expanding liquidity and credit in line with the growing potential of the economy. (Council of Economic Advisers, 1962, p. 85)

Monetary policy as well as debt management policy must be coordinated with fiscal policy to secure the objectives of high employment and growth without inflation. We are, and for some time still will be, in a situation of substantial slack in labor force and capital resources, a situation in which expansionary policies are required...What matters most at this time is that financial policy should be designed to facilitate rather than retard the expansionary process which the tax program is designed to launch. (Council of Economic Advisers, 1963, p. 55)

A decade later, perspectives on the effectiveness of monetary policy had changed; and, in some circles, monetary policy was viewed as equally important as fiscal policy for affecting both inflation and output fluctuations:

The past 10 years have been characterized by an average growth rate of aggregate expenditures that is very high by historical standards and that has substantially outstripped the sustainable growth of supply of real goods and services. Contributing significantly to the growth of aggregate demand were rapidly increasing Government expenditures along with monetary policies that were appreciably more expansionary than those in earlier postWorld War II periods...When the inflationary phase has lasted so long that expectations of further inflation are firmly embedded in the cost trend, a shift to policies of restraint first exerts an adverse influence on output and the desired price deceleration effect materializes only with a lag. Any convincing interpretation of the events during 1970 and 1973-4 must stress this difficulty. (Council of Economic Advisers, 1975, pp. 128-29)

This was not the only view of monetary and fiscal policy at that time. The 1960s saw the rise of "monetarism" subsequent to the work of Friedman and Schwartz (1963), Friedman and Meiselman (1963), and Andersen and Jordan (1968). There were several planks in the monetarism platform. First and foremost was that sustained inflation was a monetary phenomenon and that central banks should be held accountable for maintaining price stability. Monetarists contended that central banks should control the stock of money in the economy, and not focus on targeting short-term nominal interest rates, as the mechanism to achieve this long-run inflation objective. The rationale for the focus on the growth of the money stock was that, in a fiat money economy, the money stock provided the nominal anchor for the system. 
In the eyes of monetarists, inflation control was not the only concern of the monetary authorities. They saw monetary policy as having significant effects on short-run fluctuations in real output (Andersen and Jordan, 1968; and Andersen and Carlson, 1970), though not affecting long-run output growth. Indeed, many monetarists (see Brunner and Meltzer, 1968; Meltzer, 1976, 2003; and Friedman and Schwartz, 1963) believed monetary policy was responsible for aggravating, not attenuating, historical cyclical fluctuations in real output.

With the "rational expectations revolution" in macroeconomics came the "policy ineffectiveness proposition" of the New Classical Macroeconomics (Sargent and Wallace, 1975). The initial interpretations of this paradigm were that, in any macroeconomic model, the assumption of rational expectations would render monetary policy ineffective in influencing real output, both in the short run and long run. Hence, there was no role for monetary policy in output stabilization. Subsequent research (Fischer, 1977; Taylor, 1980; and Calvo, 1983) demonstrated that it was the interaction of the rational expectations hypothesis and an assumption of perfectly flexible wages and/or prices that generated the "policy ineffectiveness proposition." The outgrowth of this insight was the New Keynesian perspective.

With the widespread use of New Keynesian models, the monetarist tenets about how "monetary policy" affects economic activity have become widely held throughout academia and central banking circles today, though most academics and almost all central bankers would disown a monetarist label. Money has largely disappeared from discussions on monetary policy. Fry et al. (2000, Chart 7.2, p. 123), using data from a Bank of England survey, report that in the 1970s 11 (of 22) central banks in industrial countries reported using a money and credit framework to formulate monetary policy; but, by the 1990s, only 2 of these banks maintained this framework. Von Hagen (2004, Table 4) found a negative trend from 1970 to 2002 in the fraction of titles of articles in major economics journals that included the word "money," though the frequency of titles including "inflation" was relatively constant. He also found that the frequency of "money" in the annual reports of major central banks declined over the period 1996-2002 (Von Hagen, 2004, Table 5). King (2002) notes that

there is a paradox in the role of money in economic policy. It is this: that as price stability has become recognized as the central objective of central banks, the attention actually paid by central banks to money has declined. (p. 162)

The decline and fall of money in policy formation is confirmed by a fall in the number of references to money in speeches of central bank governors. So much so that over the past two years, Governor Eddie George has made one reference to money in 29 speeches, Chairman Greenspan one in 17, Governor Hayami one in 11 and Wim Duisenberg three in 30. (pp. 162-63)

In contemporary literature, models, and policy discussions, attention is given to the role of an inflation objective in a central bank "policy rule" as the nominal anchor in a fiat money economy. “Taylor rules" (Taylor, 1993) that specify a systematic relation between the target for a short-term interest rate and deviations of inflation from an inflation target and of real output from a measure of "potential output" have become the norm for the analysis of the impact of monetary policy. ${ }^{1}$ In this "rule like" environment, the setting of the interest rate value is the policy action; the policy itself is represented by the parameters of the "rule," including the inflation objective $\left(\pi^{*}\right)$ and the respective weights that are assigned to deviations of observed inflation from that objective and deviations of real output from "potential output."

\footnotetext{
1 There is an active discussion in the contemporary literature over the design of monetary policy rules. Some economists (for example, Svensson, 2005) argue for instrument rules that are optimized from an objective function of the central bank and models of the macroeconomy. Others (for example, McCallum and Nelson, 2004) argue for independently constructed target rules in the spirit of Taylor (1993). Both sides in this debate appear to accept the proposition that monetary policy can affect both inflation and real output in the short run, but only inflation in the long run. Hence, this theoretical debate is about how to best implement monetary policy rules, not about the effectiveness of policy.
} 


\section{Table 1}

\section{Inflation-Targeting Countries by Year of Adoption}

\begin{tabular}{|c|c|c|}
\hline Year & Country & Total \\
\hline 1990 & $\begin{array}{c}\text { New Zealand } \\
\text { Chile }\end{array}$ & 2 \\
\hline 1991 & $\begin{array}{c}\text { Canada } \\
\text { Israel }\end{array}$ & 2 \\
\hline 1992 & United Kingdom & 1 \\
\hline 1993 & $\begin{array}{l}\text { Sweden } \\
\text { Australia } \\
\text { Finland* }\end{array}$ & 3 \\
\hline 1994 & $\begin{array}{c}\text { Peru } \\
\text { Spain* }\end{array}$ & 2 \\
\hline 1995 & - & 0 \\
\hline 1996 & - & 0 \\
\hline 1997 & - & 0 \\
\hline 1998 & $\begin{array}{c}\text { Czech Republic } \\
\text { Korea } \\
\text { Poland }\end{array}$ & 3 \\
\hline 1999 & $\begin{array}{l}\text { Mexico } \\
\text { Brazil } \\
\text { Colombia }\end{array}$ & 3 \\
\hline 2000 & $\begin{array}{l}\text { South Africa } \\
\text { Switzerland } \\
\text { Thailand }\end{array}$ & 3 \\
\hline 2001 & $\begin{array}{l}\text { Norway } \\
\text { Iceland } \\
\text { Hungary }\end{array}$ & 3 \\
\hline 2002 & Philippines & 1 \\
\hline
\end{tabular}

NOTE: *Finland and Spain are considered to have become non-inflation-targeting countries on joining the third stage of the European Monetary Union in 1999.

SOURCE: Authors' compilation based on monetary policy and inflation reports of each country's central bank and Mishkin and Schmidt-Hebbel (2002) and Morande (2002).

\section{LONG-RUN STABILIZATION OBJECTIVES FOR MONETARY POLICY}

Over the past 15 years, a number of countries, starting with New Zealand, have announced explicit numeric inflation objectives (the $\pi^{*}$ term in the Taylor rule framework). The relevant question is, How effective are central banks at hitting explicit numeric inflation targets?
Clearly, one straightforward way to address this question is to look at the performance of those countries that have announced explicit numeric inflation targets. Our list of the countries in this group (23 in all) is shown in Table 1. For each country, Figure 1 graphs the year a target was adopted and the inflation rate at that time..$^{2,3}$ As far as we have been able to determine, no country has joined the group since 2002. In many, but certainly not all of these countries, inflation was below 5 percent at the time of the announcement of the inflation-targeting regime. The appendix provides the details on the target index(es), the target ranges, dates of target adoption, target setting responsibility, and public reporting on the performance of the inflation policy.

Figures 2 through 22 show the history of inflation for each of the inflation-targeting countries. ${ }^{4}$ For those countries that have changed the index in which they define their inflation target, there is a separate graph for each index. The graphs show the inflation target range (the shaded area) or the point inflation target as appropriate. It is immediately apparent from these graphs that the period-to-period (month-to-month or quarterto-quarter) annualized rate of inflation is highly volatile in all of the countries that pursue an explicit numeric inflation target. These short-run inflation rates are as likely as not to be outside the target range. If effective monetary policy were to be defined in terms of stability of high-frequency rates of inflation, then all of these central banks would have to be judged as failing to achieve the objective. However, it is neither reasonable nor desirable to define the objective in such short-run terms. Shocks to the price level-that is, transitory shocks to inflation-originate from numerous sources, both monetary and nonmonetary. No central bank can foresee such shocks and probably

2 We consider two countries that at one time had explicit numeric targets-Finland and Spain - that have dropped from the group upon accession to the European Monetary Union.

3 This figure updates similar figures that can be found in Loayza and Soto (2002) and Mishkin and Schmidt-Hebbel (2002).

4 For early discussions of the implementation of and experience with inflation targeting for several of these countries, see Leiderman and Svensson (1995). 


\section{Figure 1}

\section{The Year of Adoption and Initial Inflation in Twenty-Three Inflation-Targeting Countries}

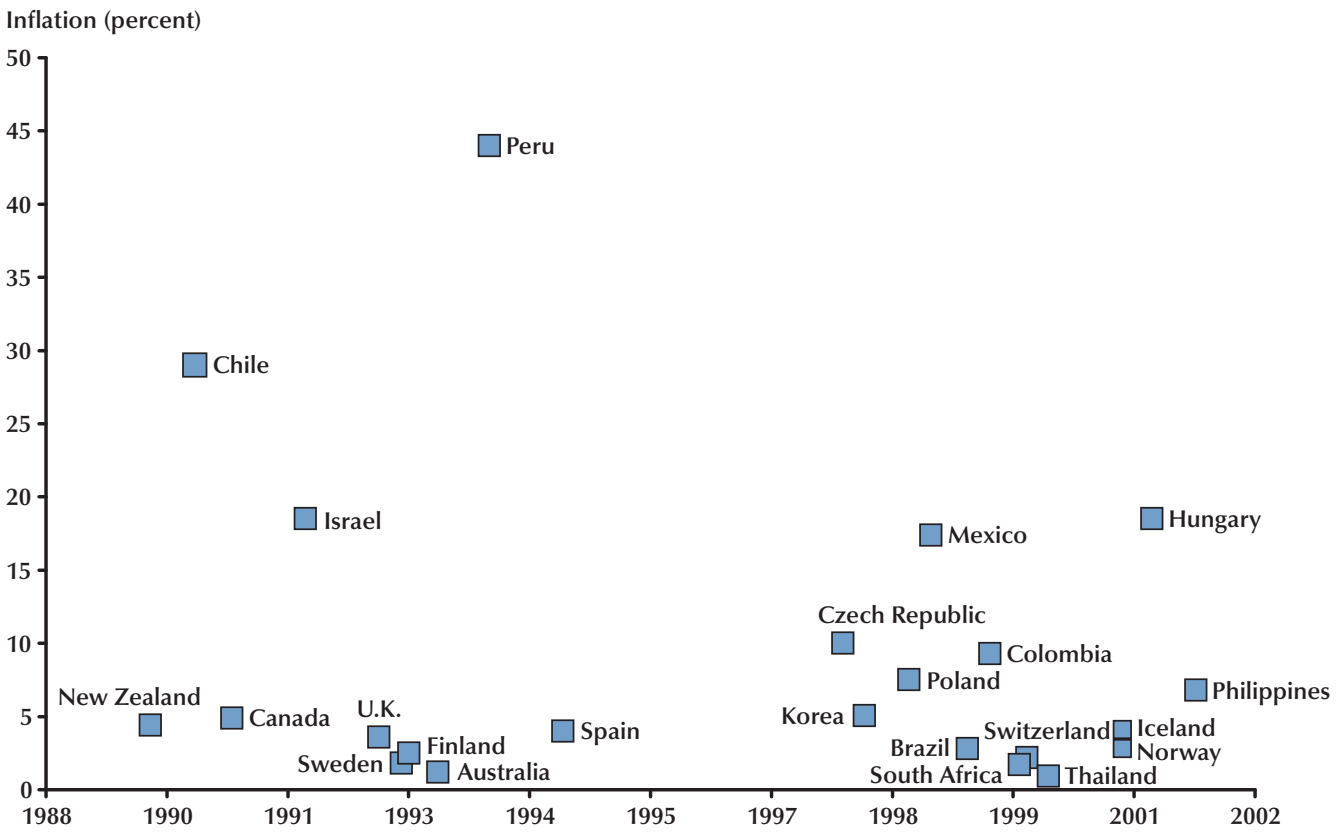

cannot accurately predict the dynamics by which such shocks ultimately impact the price level. Economic theory suggests that central banks can be held accountable for "sustained inflation." Correspondingly, inflation-targeting central banks, and even central banks without explicit numeric targets, such as the Fed, typically focus on "medium term" inflation. The duration of the medium term is frequently, and probably intentionally, left ambiguous. ${ }^{5}$ Absent a precise definition of the medium term, some measures must be specified to judge the effectiveness of the inflation-targeting policies.

We examine two measures of the effectiveness of explicit numeric inflation targeting. Both measures are based on moving averages of the observed rates of inflation. These measures are

5 President Santomero of the Federal Reserve Bank of Philadelphia stated that he preferred measuring inflation against an explicit target range on a 12-month moving-average (year-over-year) basis. Few central bankers have been this explicit about their definitions of a "medium term." indicated in Figures 2 to 23 by the heavy lines. Relative to the dates indicated on the horizontal axis, this line shows the leading moving average of the rate of inflation to the end of 2004. The shortest moving average shown is one year. The question is, What is the maximum period, ending with 2004, that the moving average of the inflation rate remained within the bounds determined by the current (end of 2004) inflation target? These periods are shown for each of the inflationtargeting countries in Table 2.

Judged by this metric, there are a number of inflation-targeting countries in which monetary policy has been very effective. For five countries, New Zealand, Norway, Switzerland, Thailand, and the United Kingdom, the moving average of the rate of inflation has been within the current announced target range since before the adoption of the inflation-targeting procedure. ${ }^{6}$ Canada and

${ }^{6}$ Norway has a stated target of 2.5 percent, not an inflation range. The moving average of the inflation rate has been below this value since 2000 and only dipped slightly below zero in early 2003 . 
Figure 2

\section{Australia: Moving Average of Inflation and Inflation Target Range}
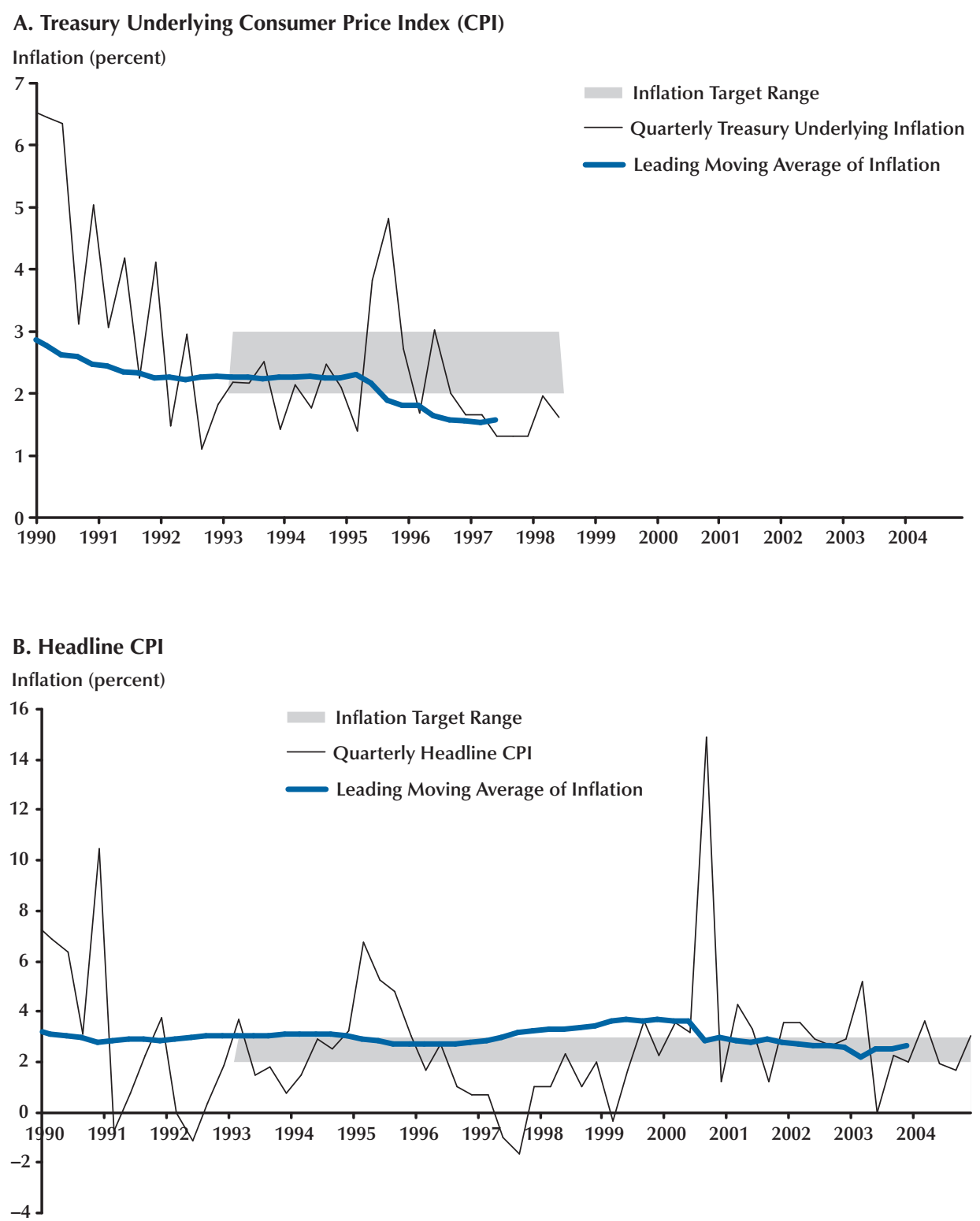

NOTE: The initial, formal inflation target related to the Treasury underlying measure of the CPI. When interest charges were removed from the CPI in the June quarter 1998, this target was amended to the headline CPI inflation rate.

SOURCE: Reserve Bank of Australia. 


\section{Figure 3}

\section{Brazil: Moving Average of Inflation and Inflation Target Range}

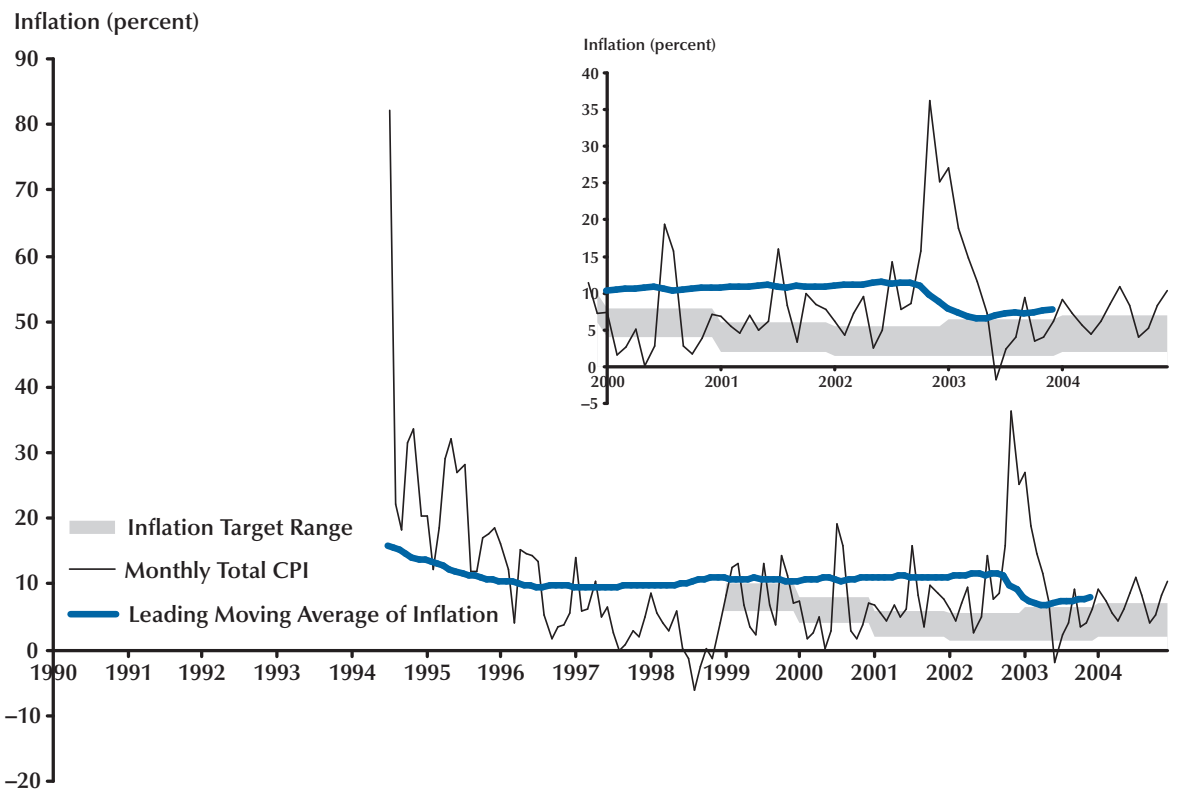

SOURCE: Banco Central do Brazil.

\section{Figure 4}

\section{Canada: Moving Average of Inflation and Inflation Target Range}

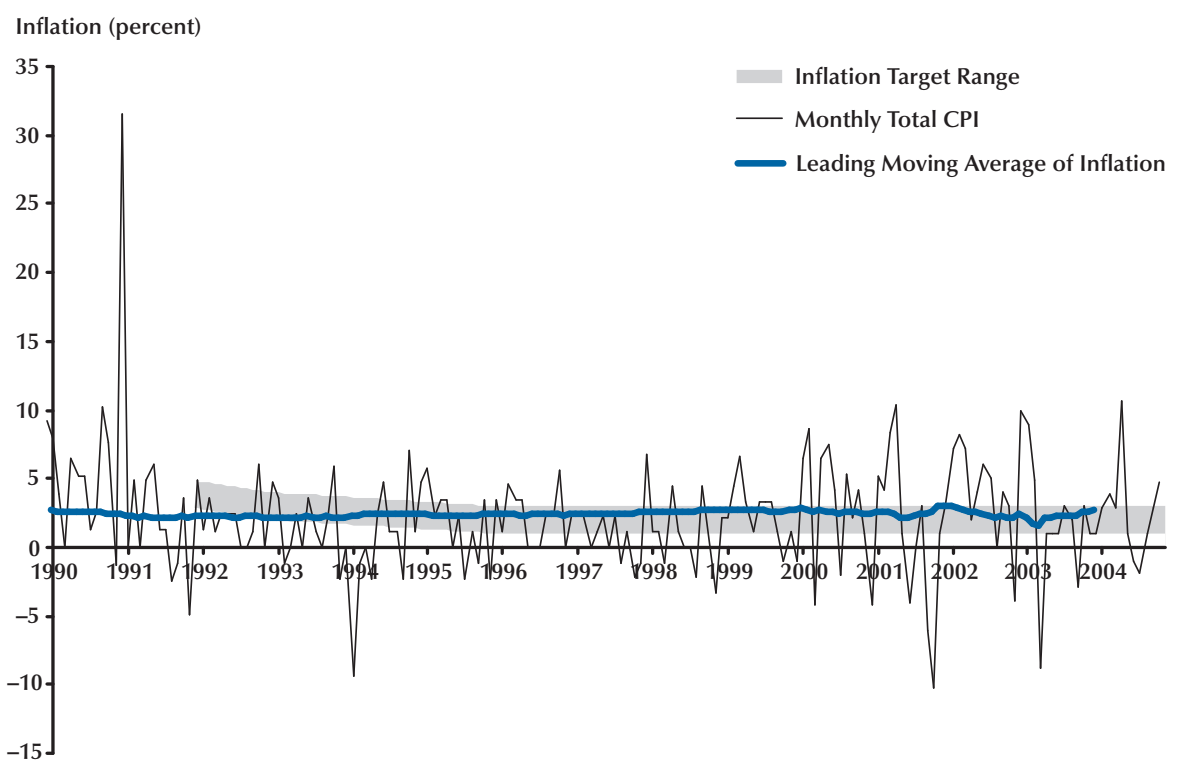

SOURCE: Banque du Canada. 
Figure 5

\section{Chile: Moving Average of Inflation and Inflation Target Range}

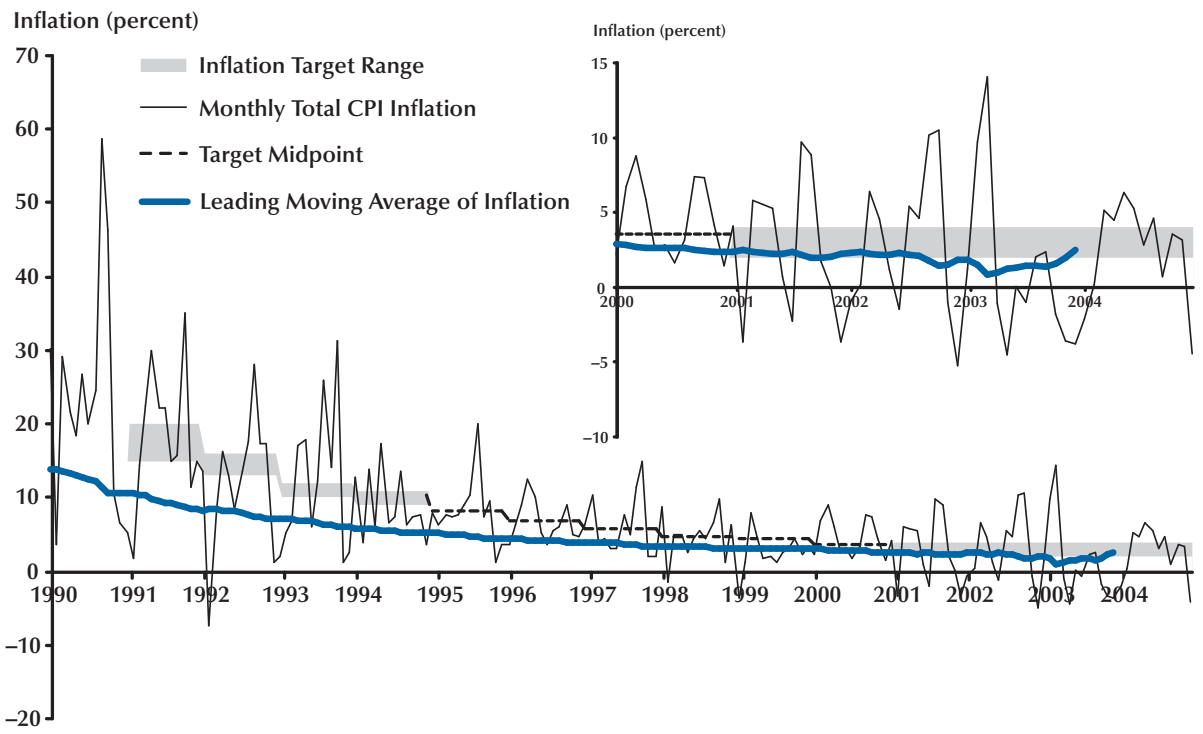

SOURCE: Banco Central de Chile.

Figure 6

\section{Colombia: Moving Average of Inflation and Inflation Target Range}

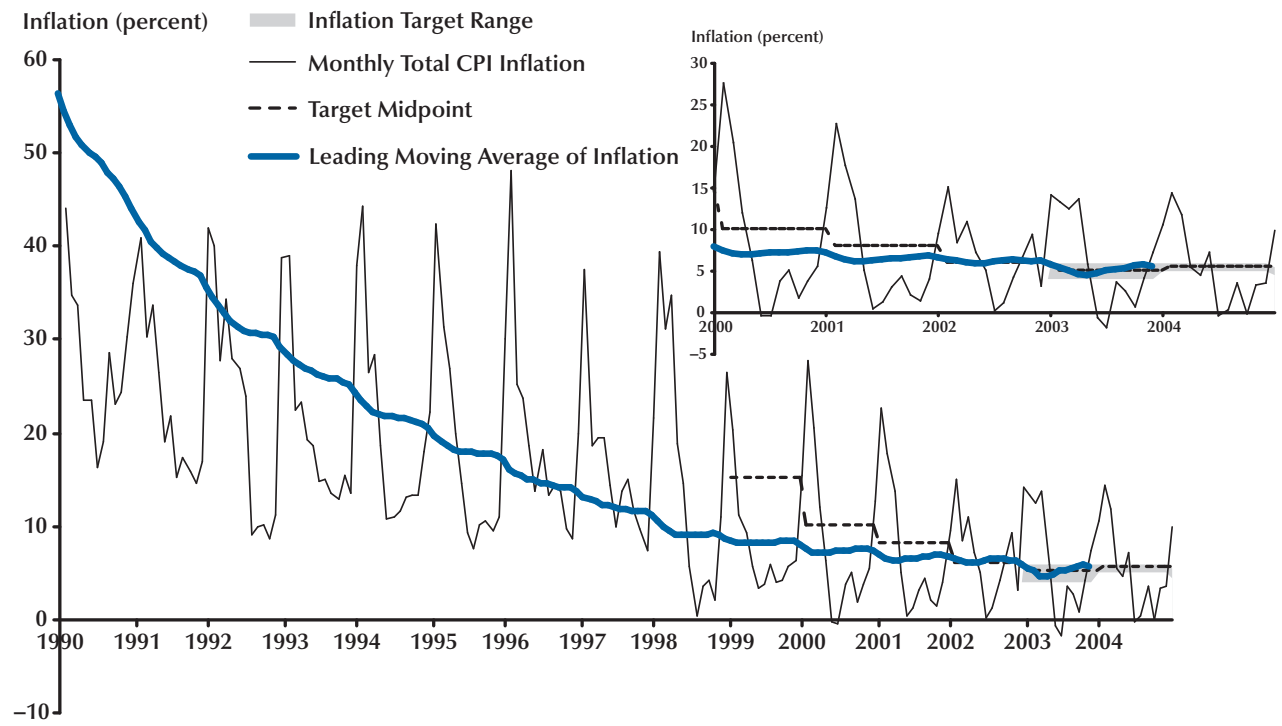

SOURCE: Banco Central de Colombia. 
Figure 7

\section{Czech Republic: Moving Average of Inflation and Inflation Target Range, Headline CPI}

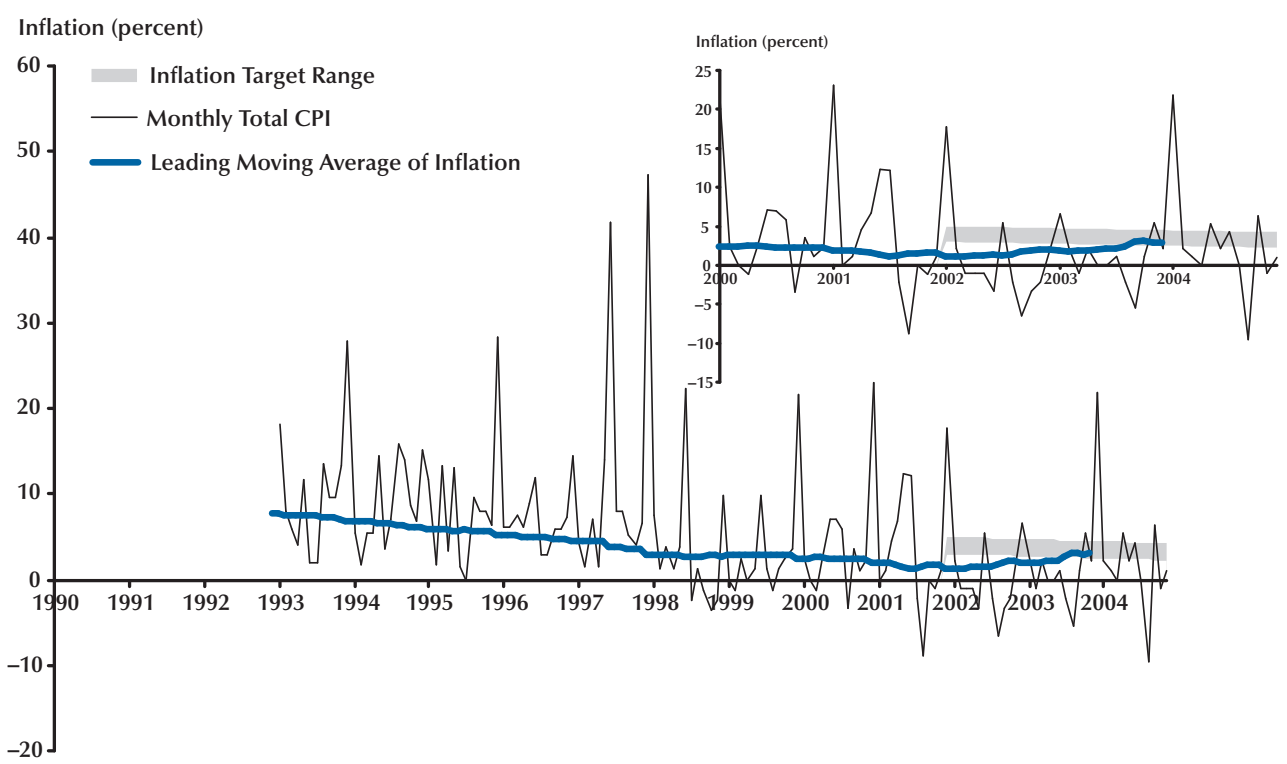

NOTE: Czech Republic targeted net inflation through 2001 and headline CPI thereafter.

SOURCE: Czech Statistical Office.

\section{Figure 8}

Hungary: Moving Average of Inflation and Inflation Target Range

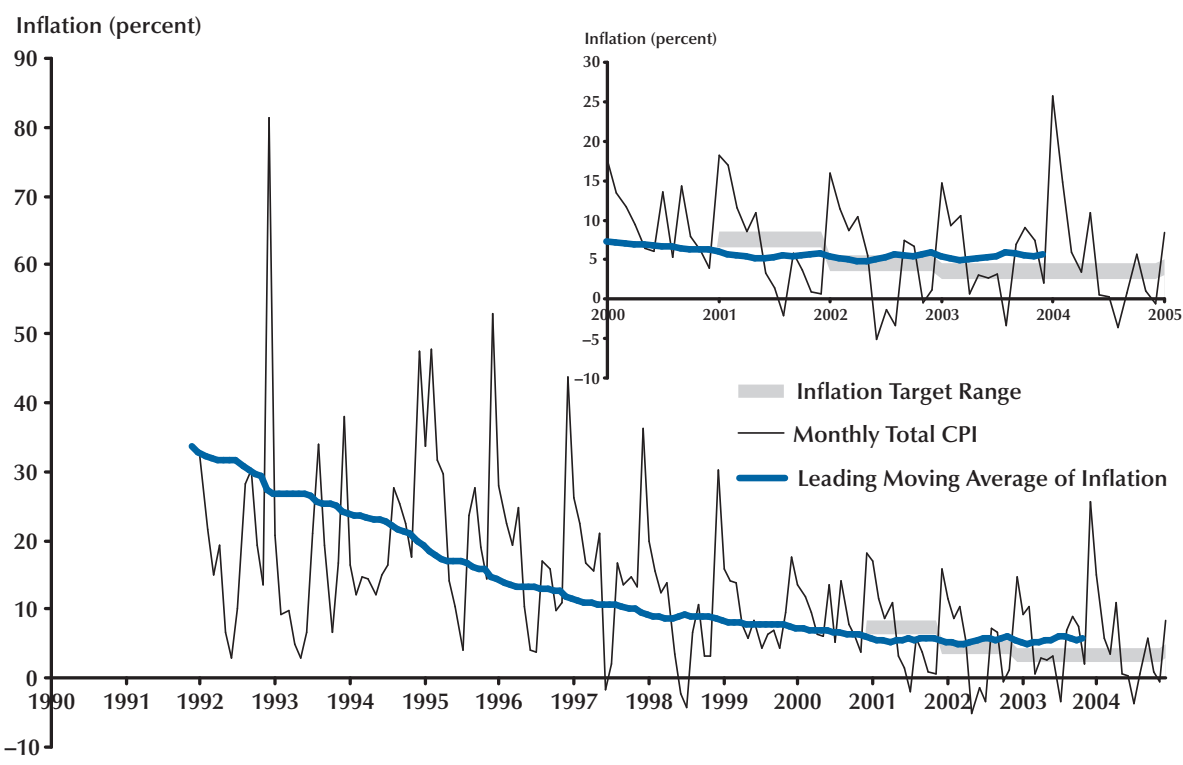


Figure 9

Iceland: Moving Average of Inflation and Inflation Target Range

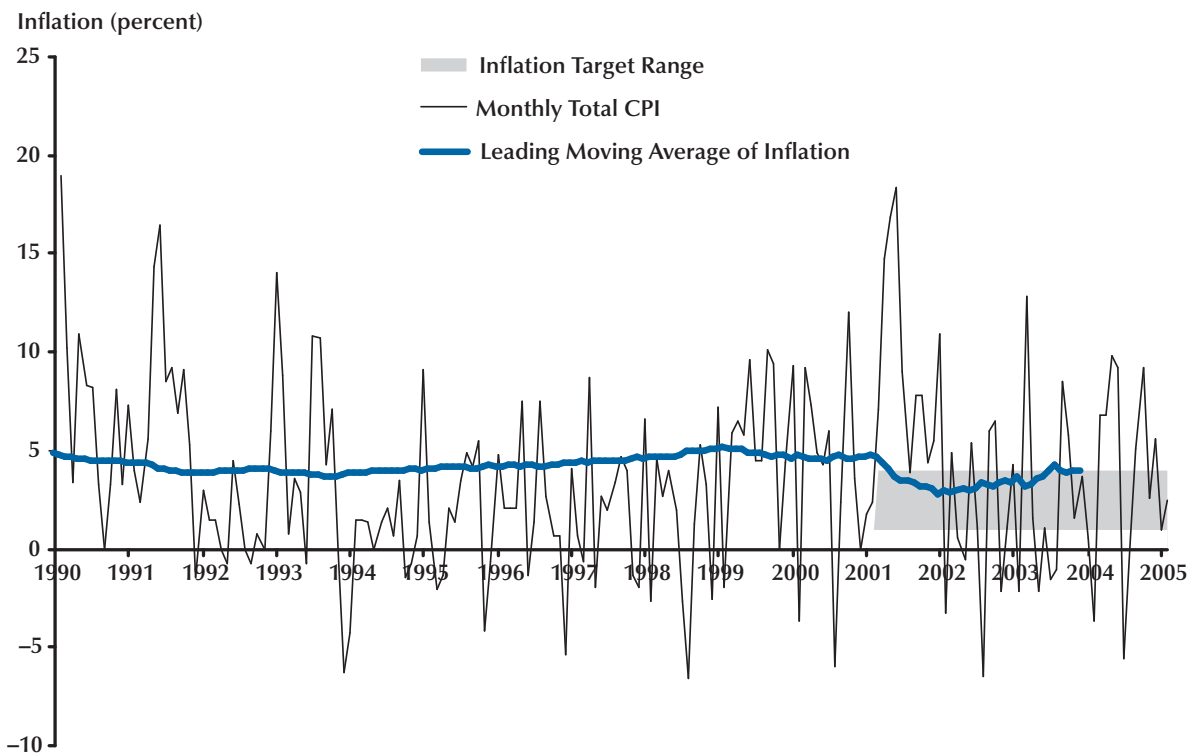

SOURCE: Statistics Iceland.

\section{Figure 10}

\section{Israel: Moving Average of Inflation and Inflation Target Range}

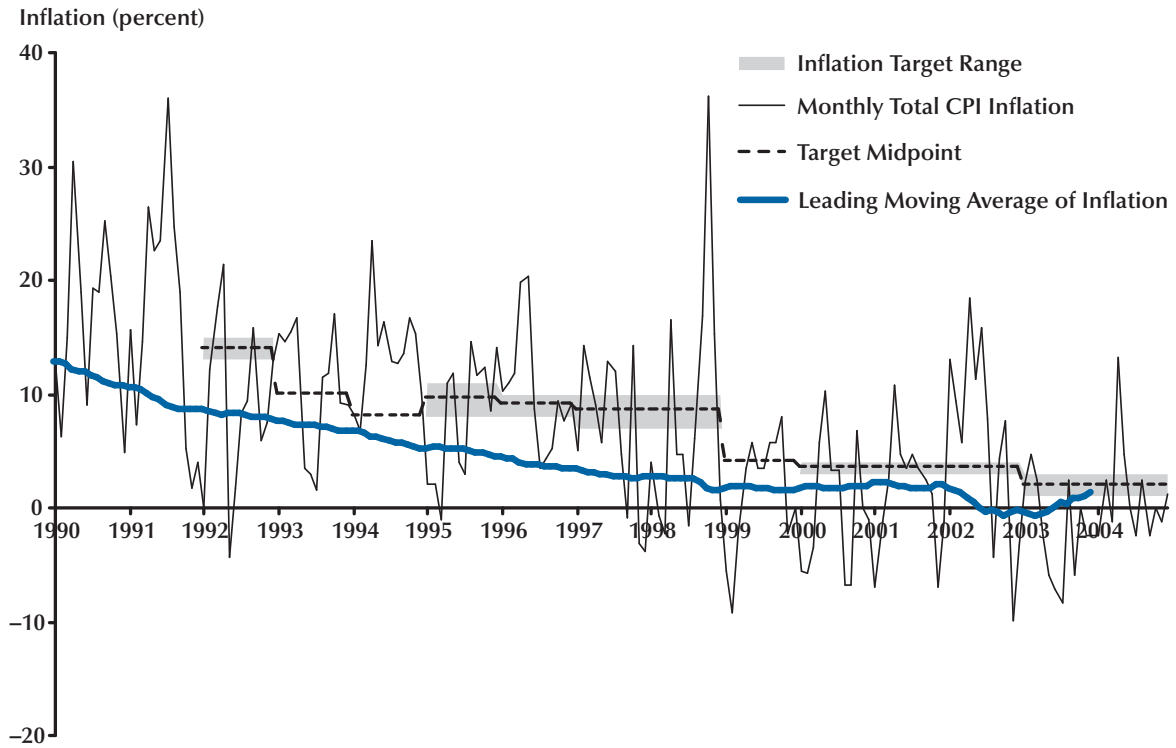

SOURCE: Central Bureau of Statistics, Israel. 


\section{Figure 11}

\section{Korea: Moving Average of Inflation and Inflation Target Range}

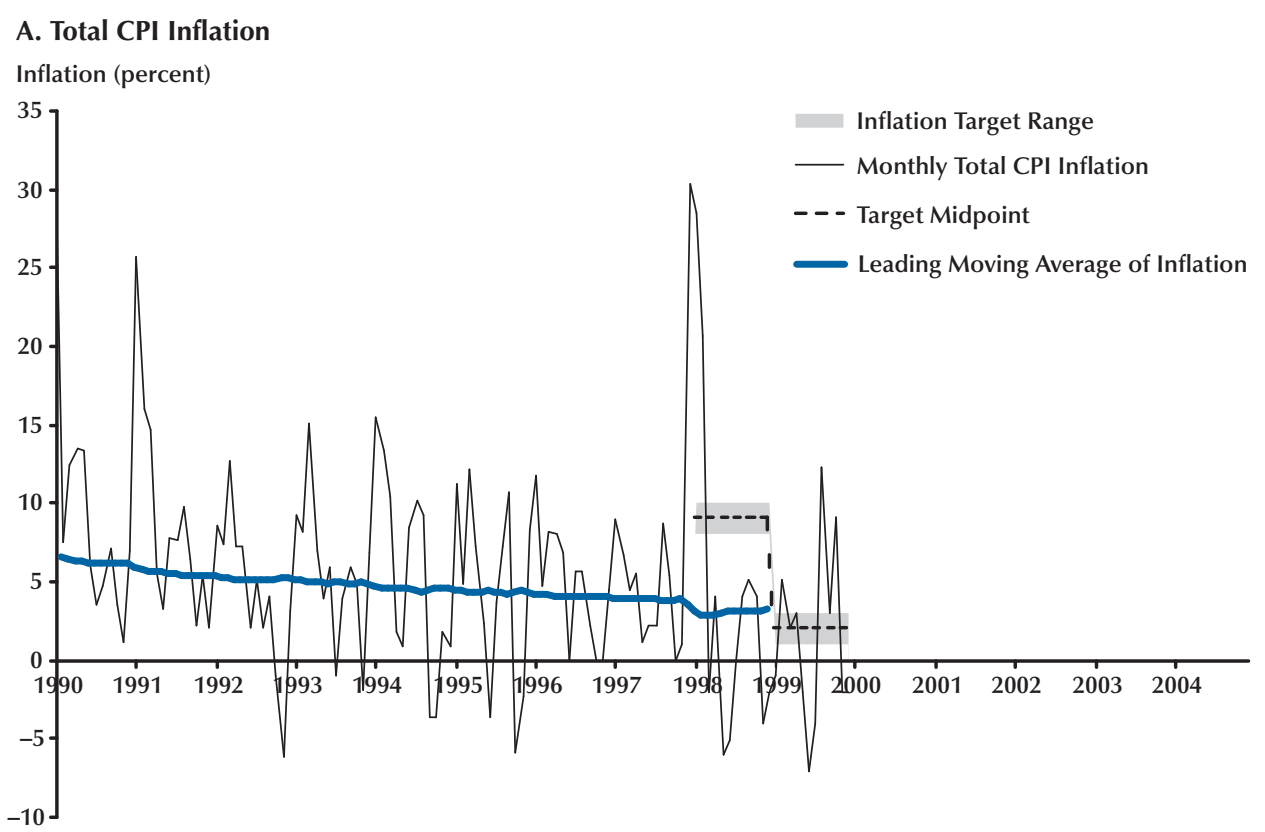

\section{B. Core CPI Inflation}

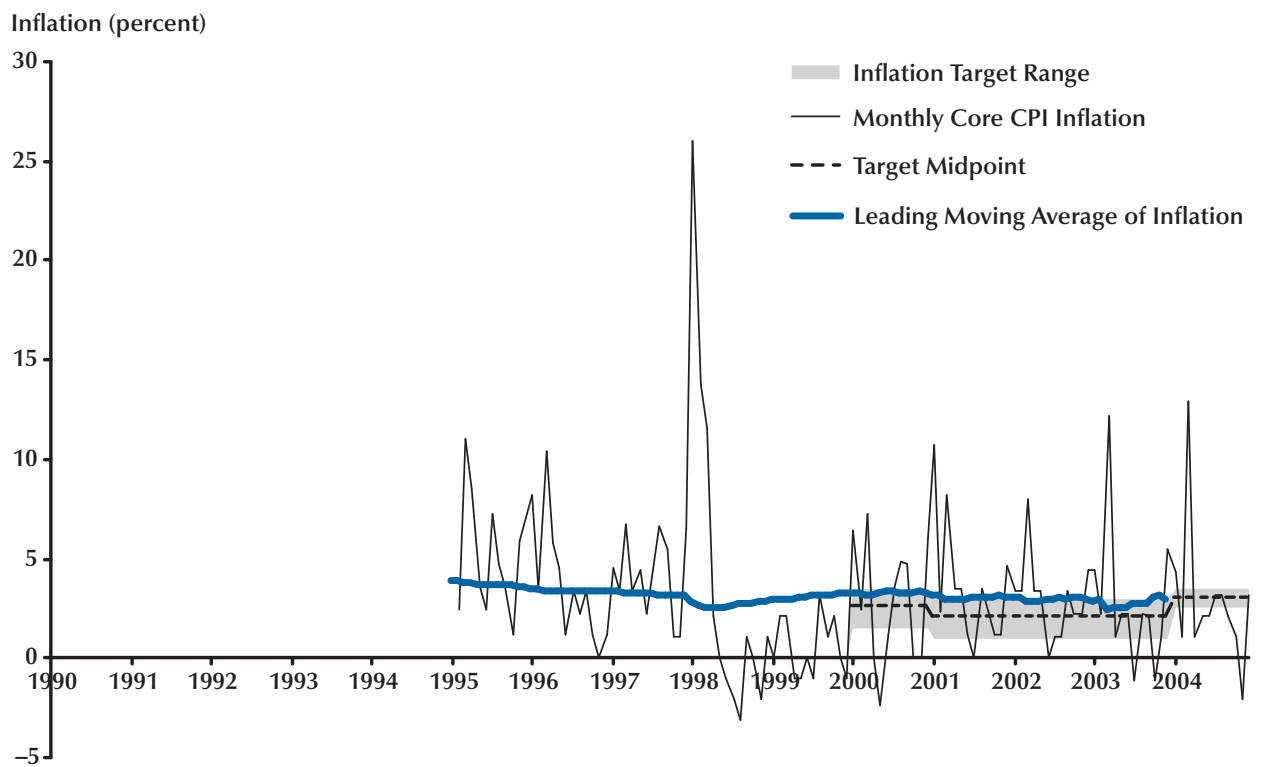

NOTE: Total CPI was targeted until 1999. Core inflation was targeted beginning in 2000.

SOURCE: Korea National Statistics Office and the Bank of Korea. 
Figure 12

Mexico: Moving Average of Inflation and Inflation Target Range

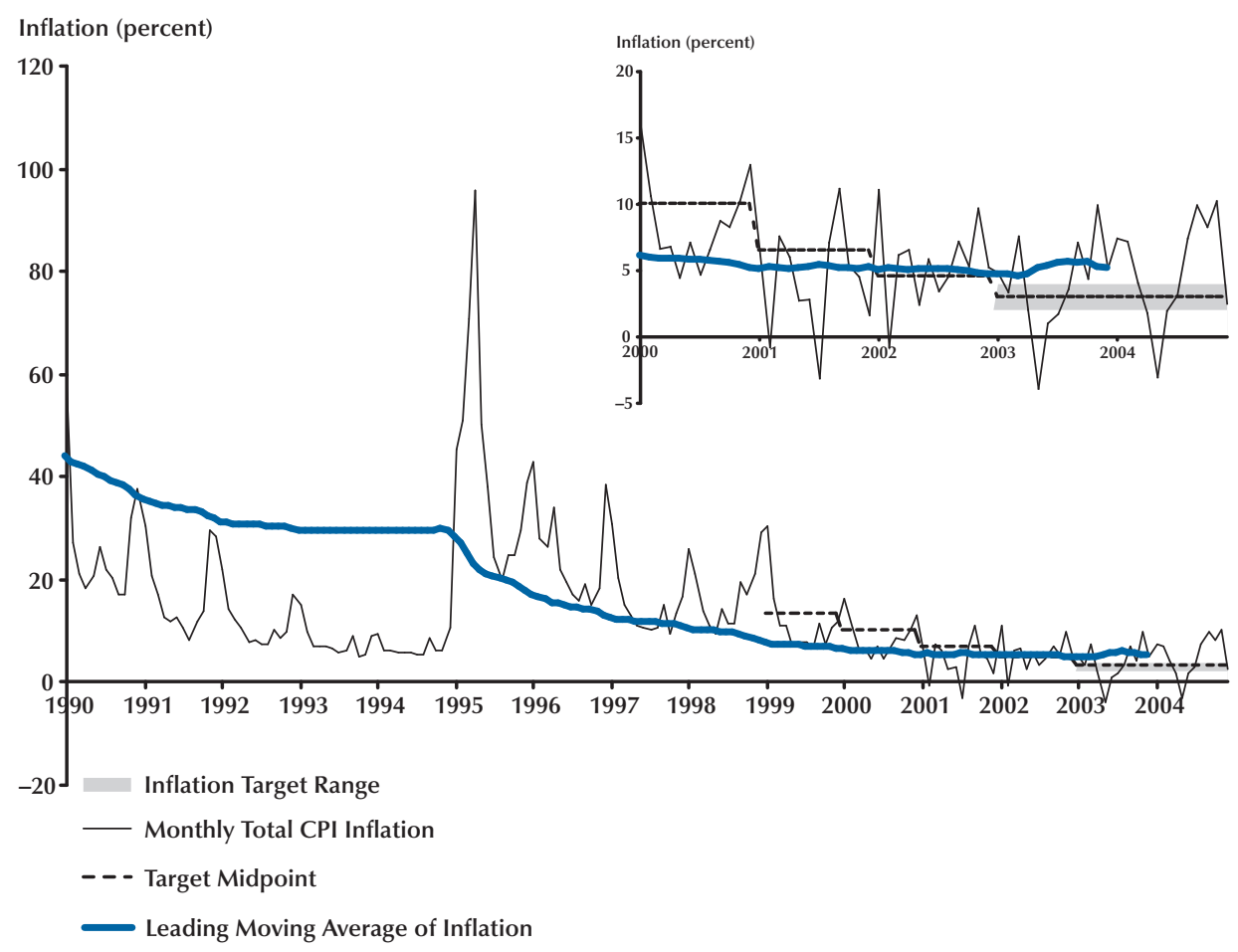

SOURCE: Banco de Mexico. 


\section{Figure 13}

\section{New Zealand: Moving Average of Inflation and Inflation Target Range}
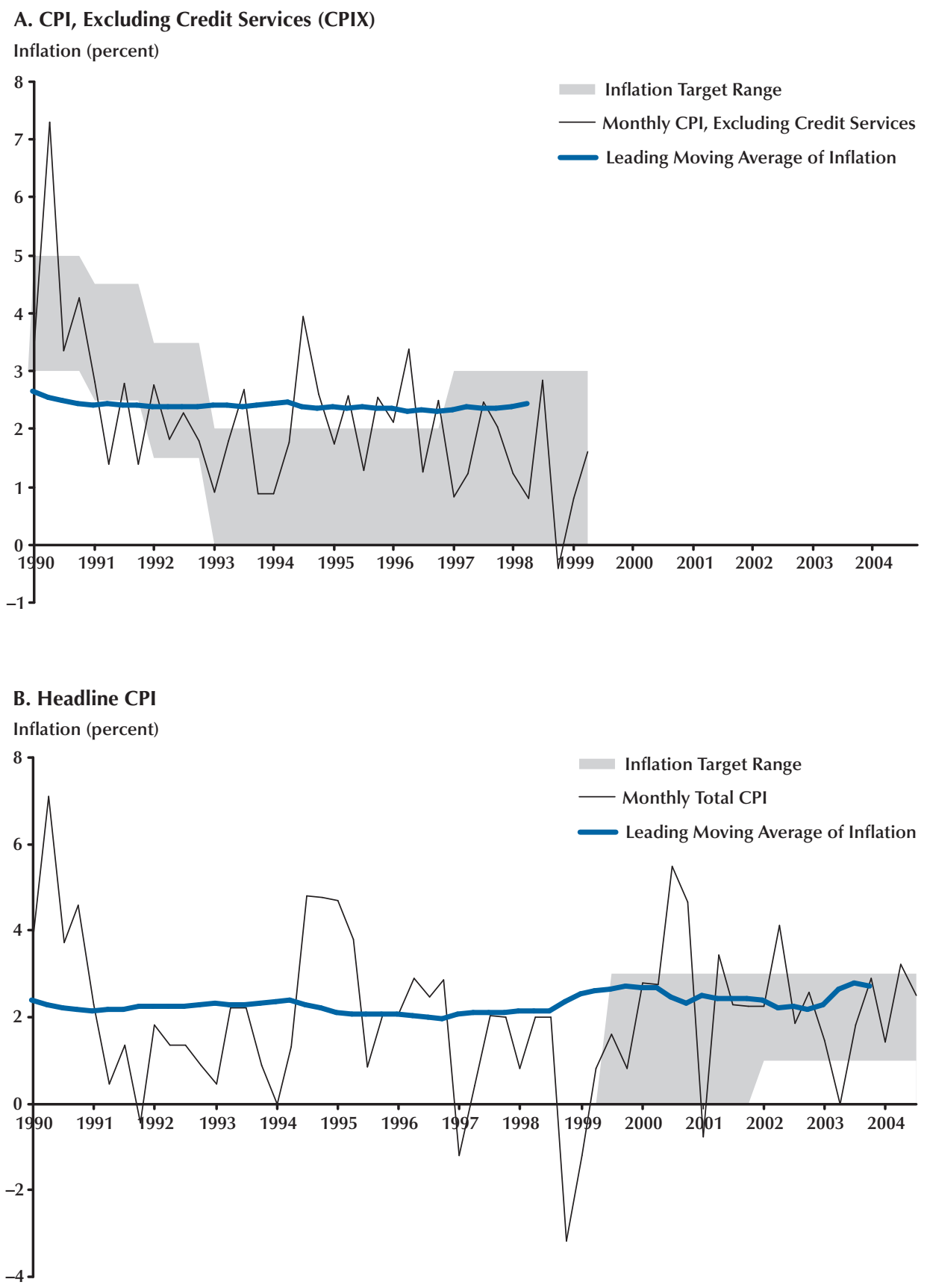

NOTE: The Reserve Bank of New Zealand targeted underlying inflation until the September 1997 quarter, CPIX inflation through to the June 1999 quarter, then CPI inflation from the September 1999 quarter.

SOURCE: Reserve Bank of New Zealand. 
Figure 14

Norway: Moving Average of Inflation and Inflation Target Range

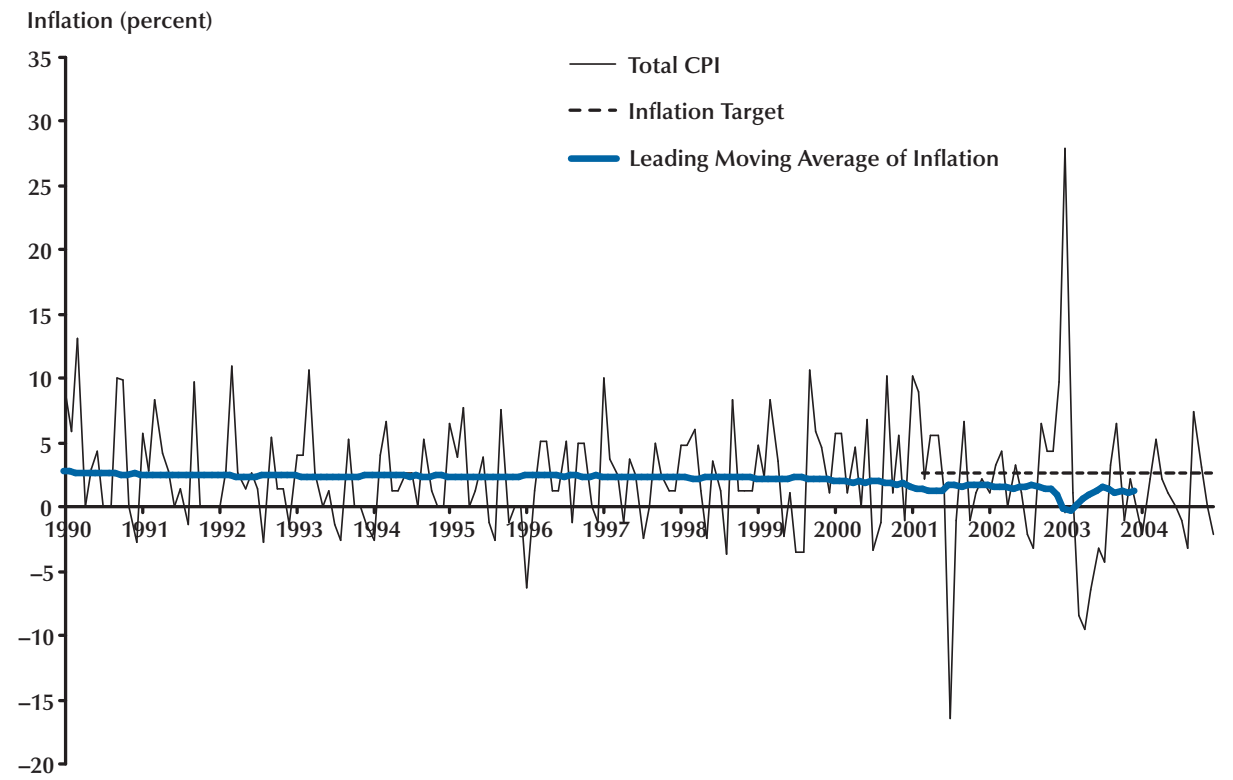

SOURCE: Statistics Norway.

\section{Figure 15}

\section{Peru: Moving Average of Inflation and Inflation Target Range}

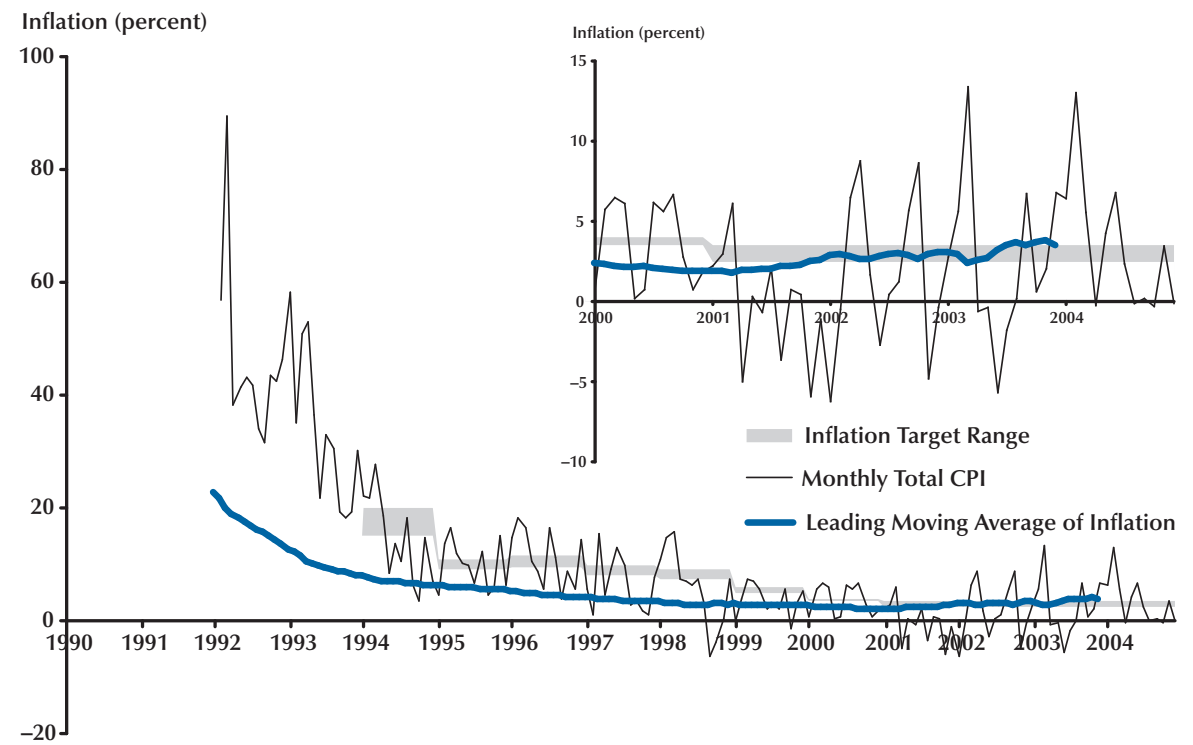

SOURCE: Central Reserve Bank of Peru. 


\section{Figure 16}

\section{Philippines: Moving Average of Inflation and Inflation Target Range}

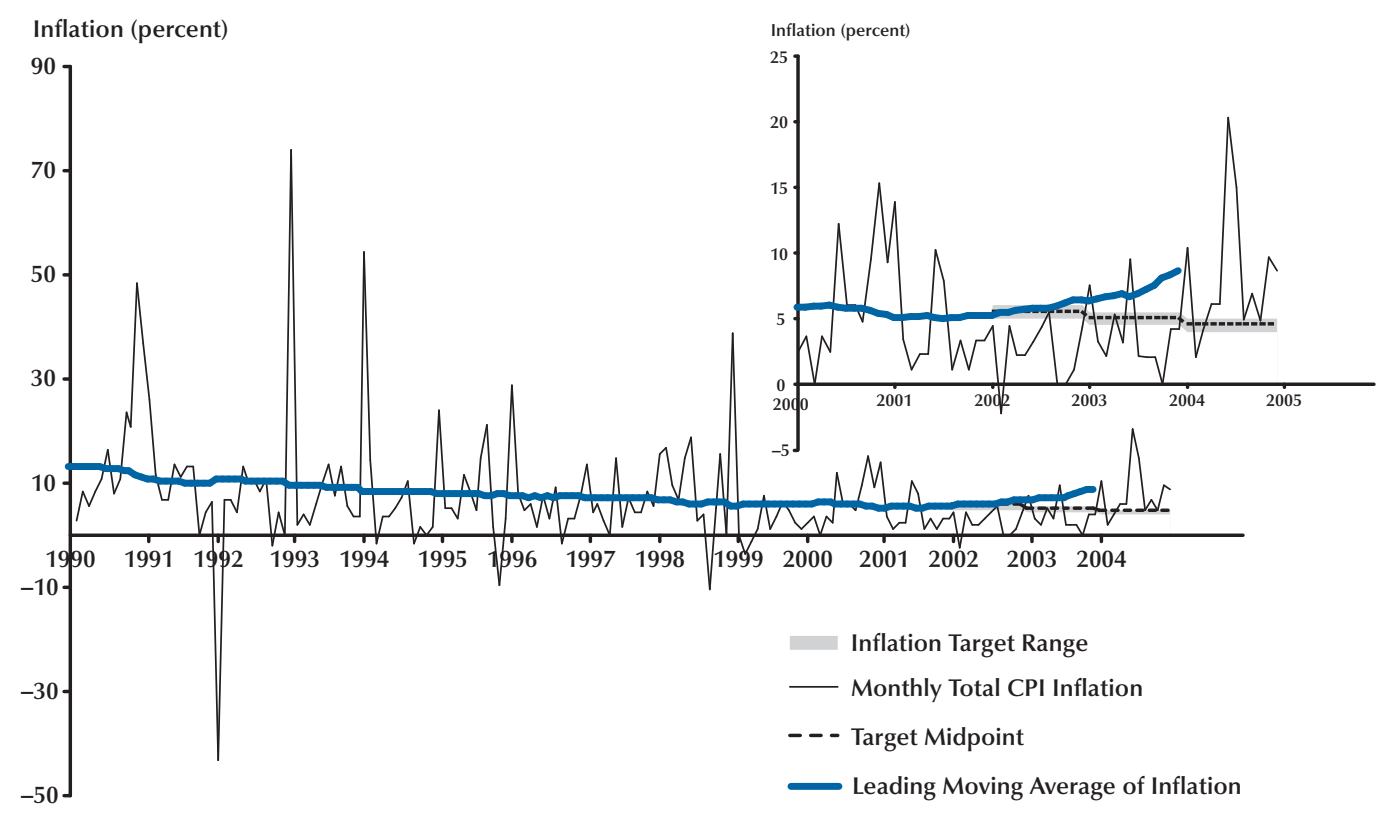

SOURCE: Central Bank of the Philippines.

\section{Figure 17}

\section{Poland: Moving Average of Inflation and Inflation Target Range}

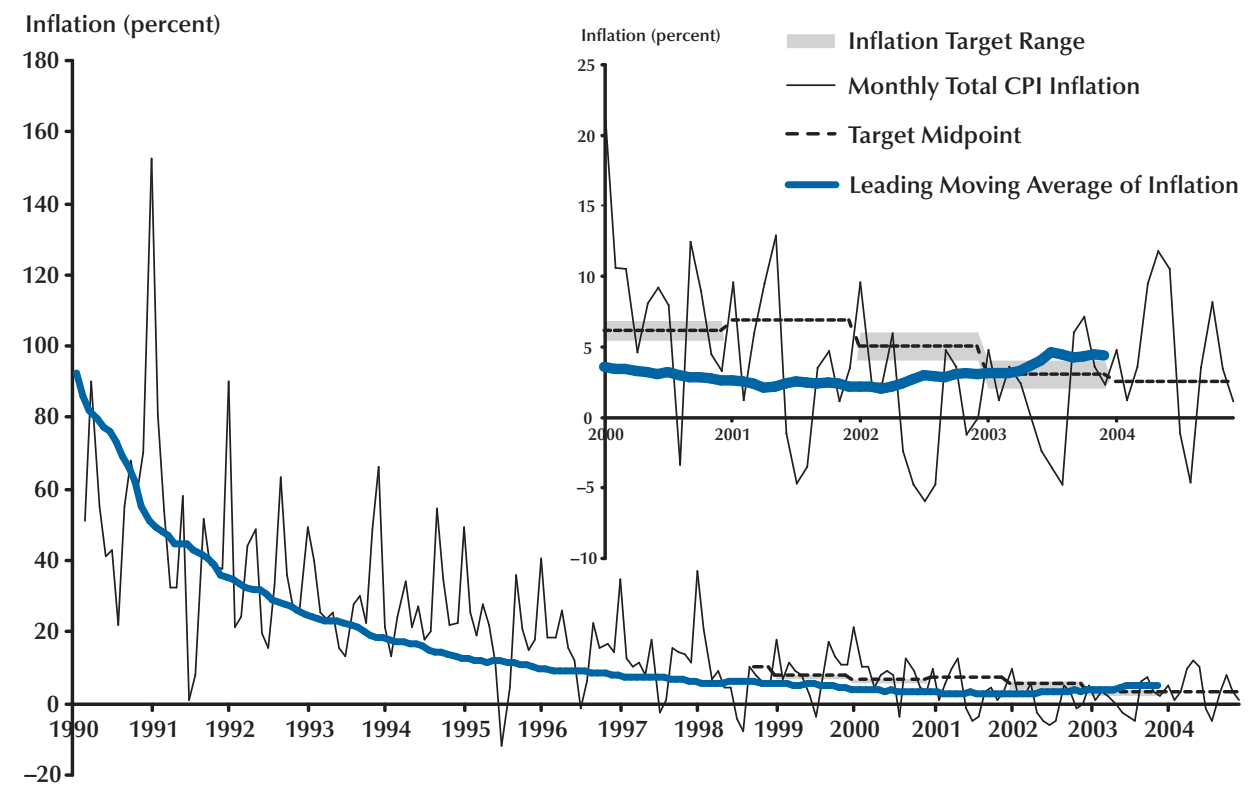

SOURCE: Central Statistical Office, Poland. 
Figure 18

South Africa: Moving Average of Inflation and Inflation Target Range

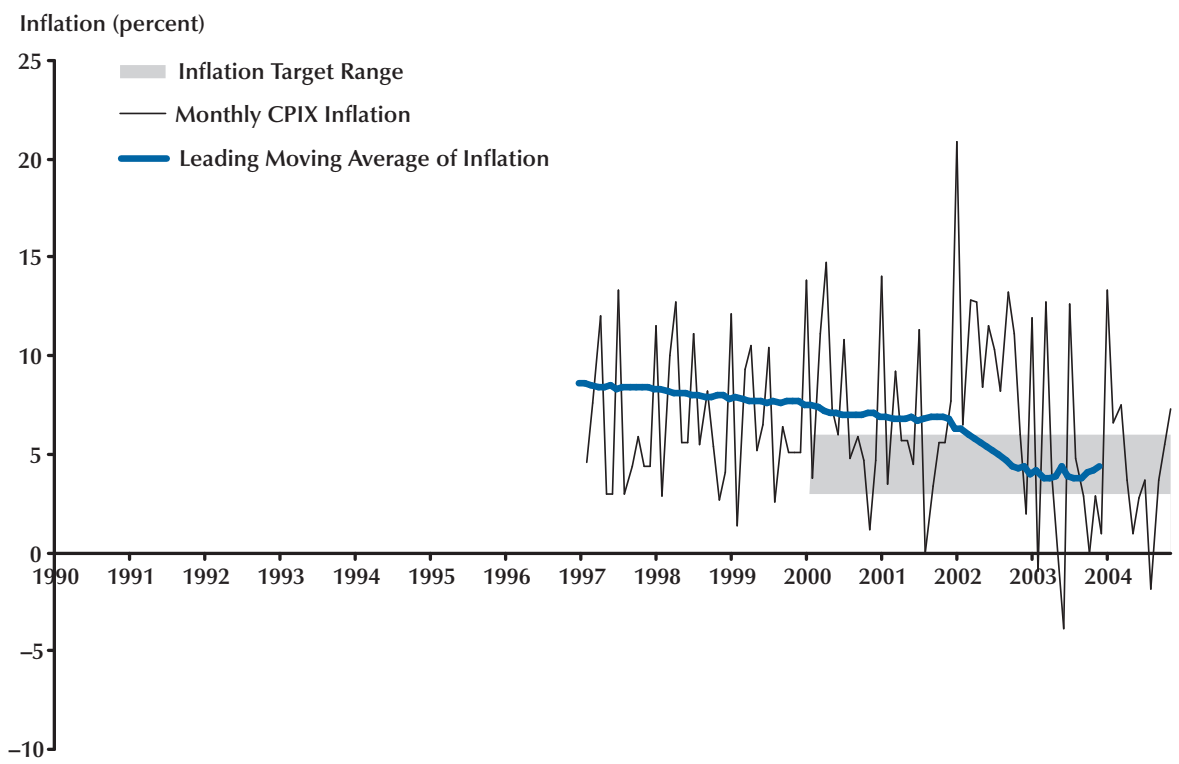

SOURCE: South African Reserve Bank.

\section{Figure 19}

\section{Sweden: Moving Average of Inflation and Inflation Target Range}

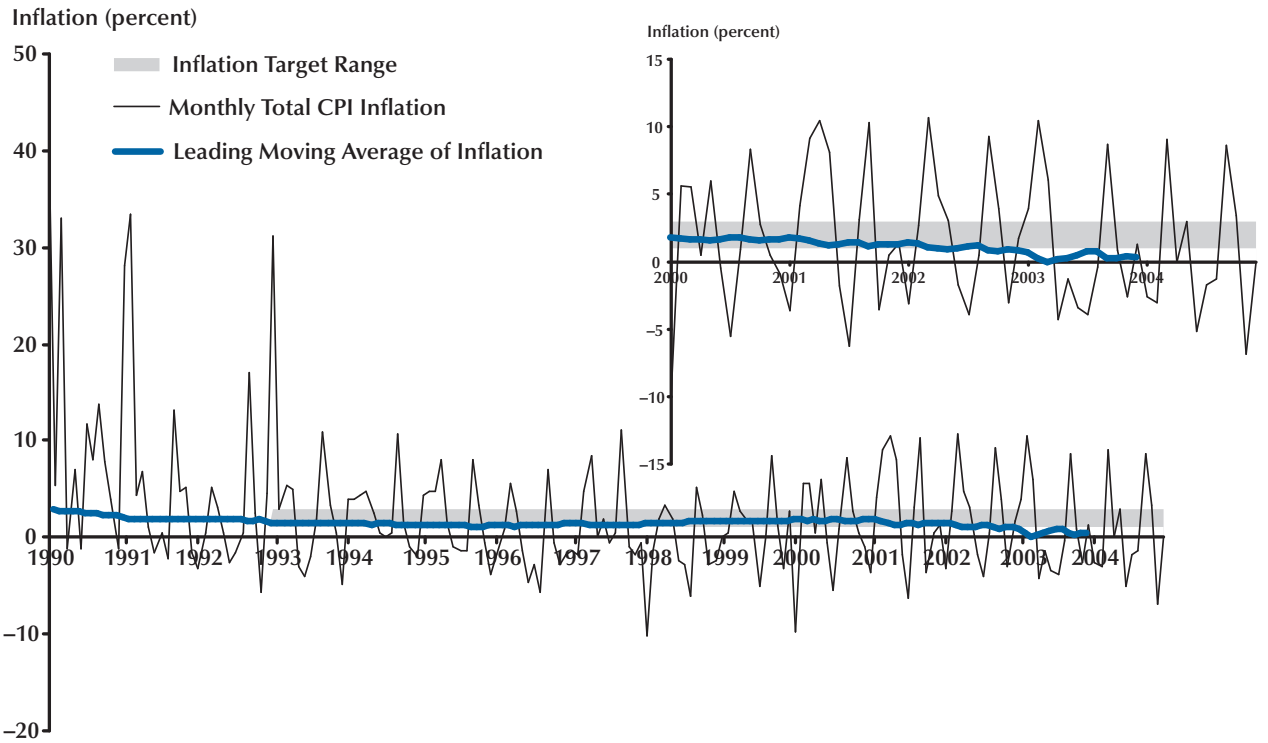


Figure 20

\section{Switzerland: Moving Average of Inflation and Inflation Target Range}

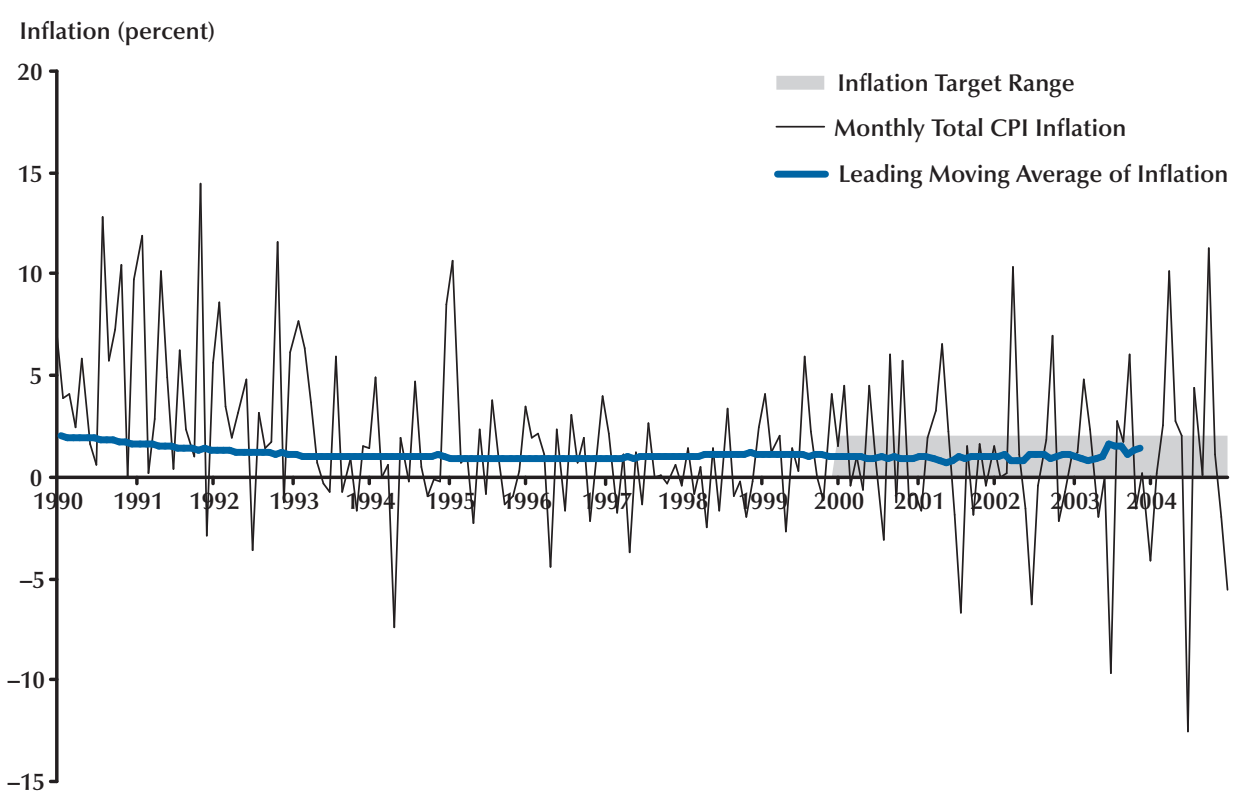

SOURCE: Swiss National Bank.

Figure 21

Thailand: Moving Average of Inflation and Inflation Target Range

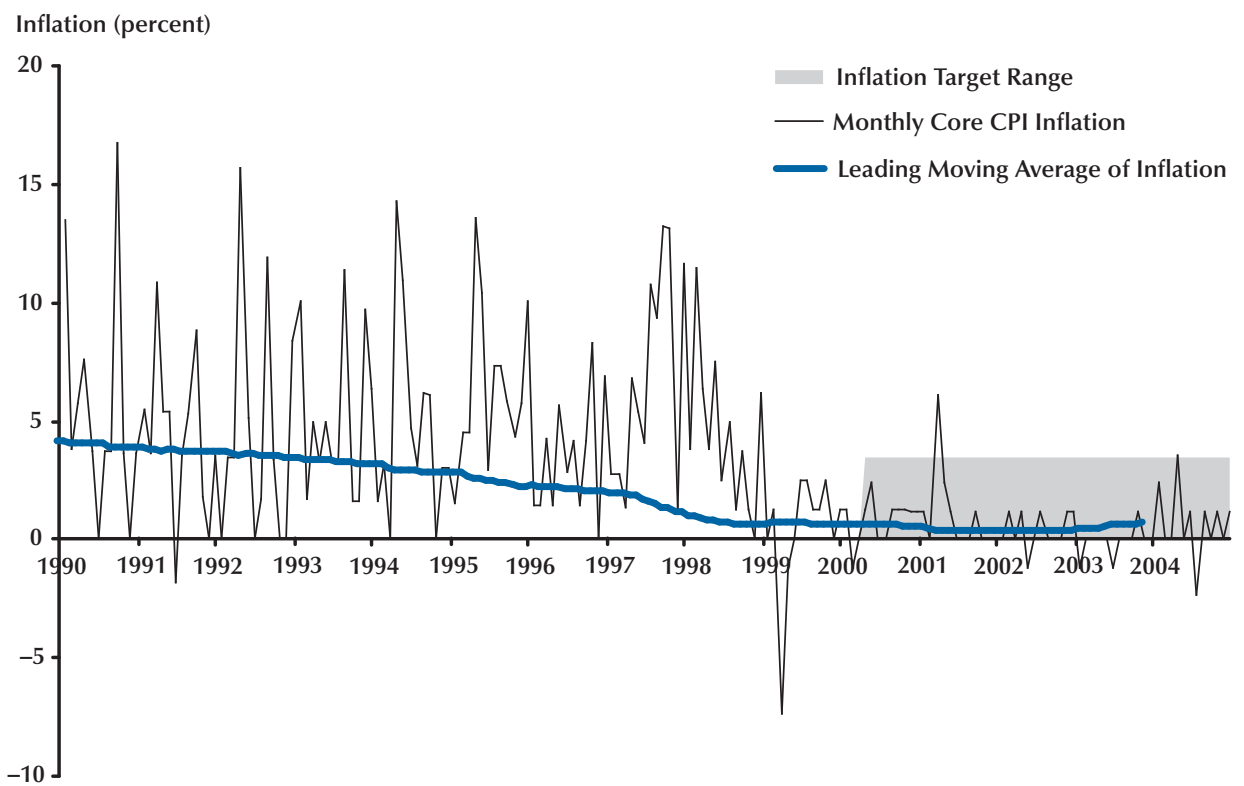

SOURCE: Bureau of Trade and Economic Indices, Ministry of Commerce, Thailand. 
Figure 22

\section{United Kingdom: Moving Average of Inflation and Inflation Target Range}

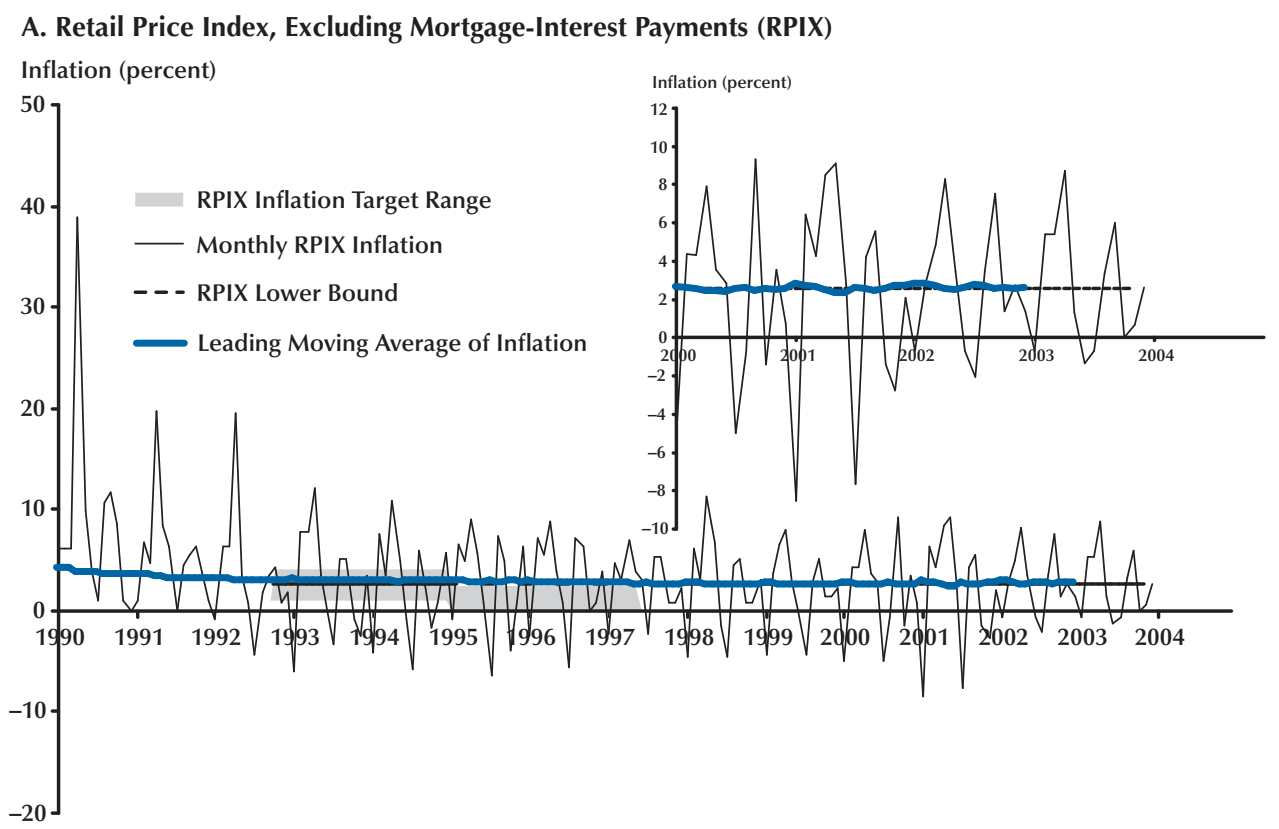

\section{B. CPI}

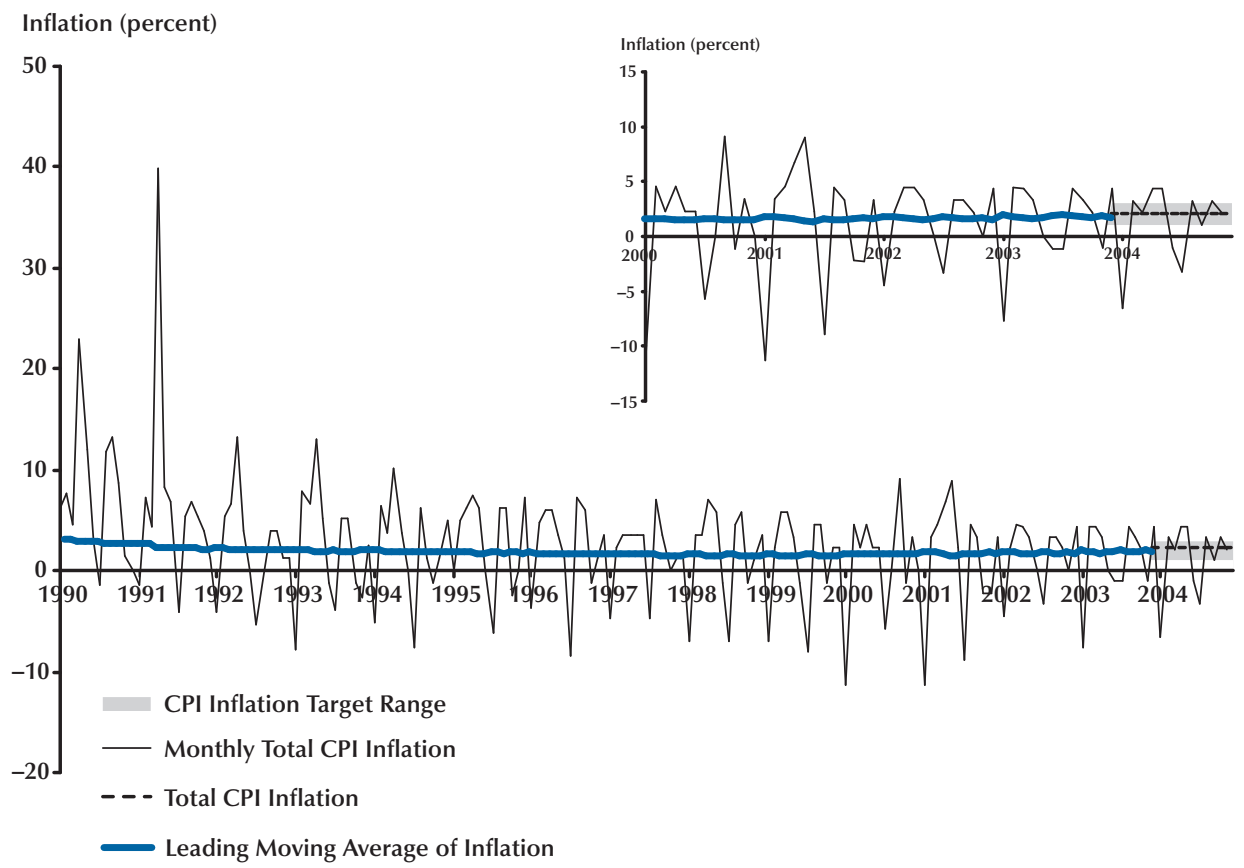

NOTE: Since December 2003, the United Kingdom's inflation target has been based on the CPI.

SOURCE: National Statistics, United Kingdom. 
Figure 23

\section{United States: Moving Average of Inflation and Inflation Target Range}

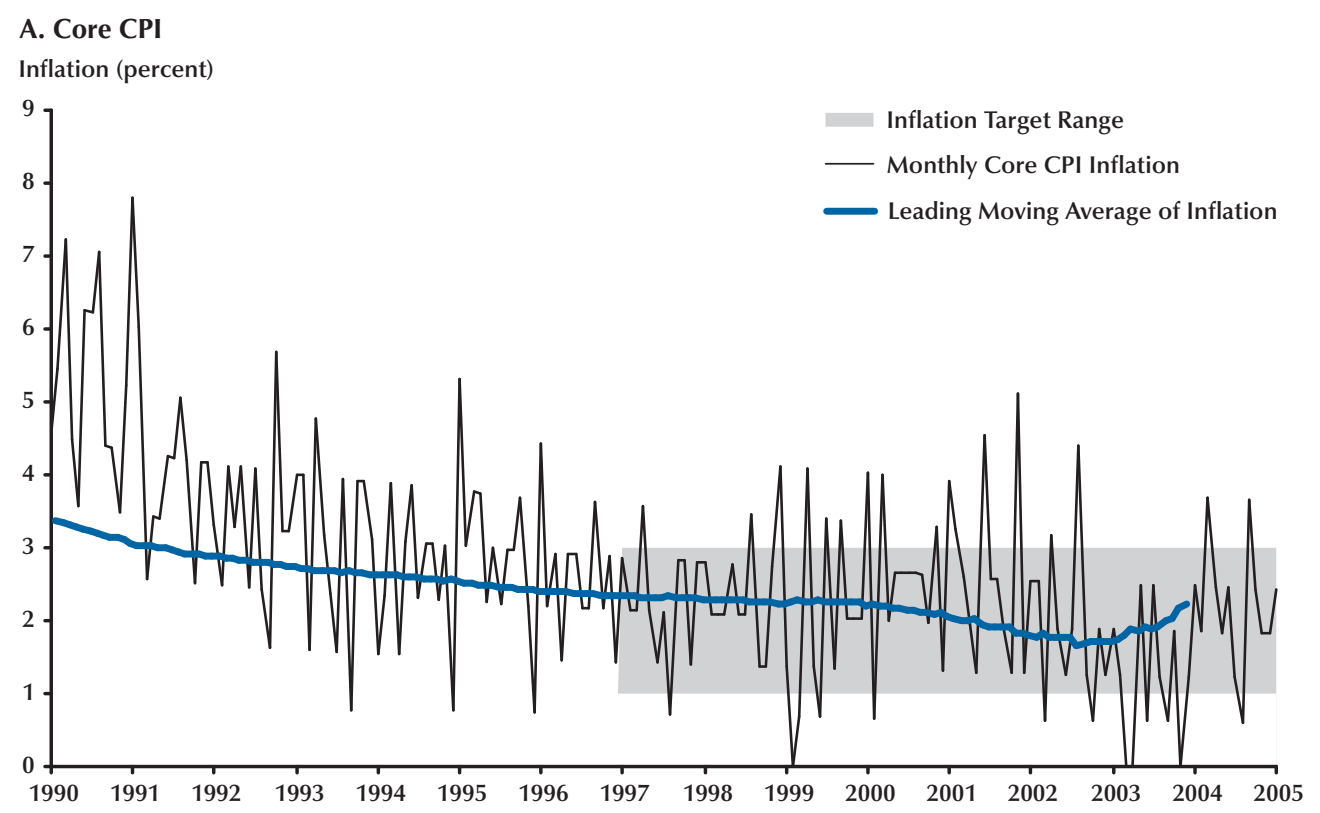

\section{B. Core PCE}

Inflation (percent)

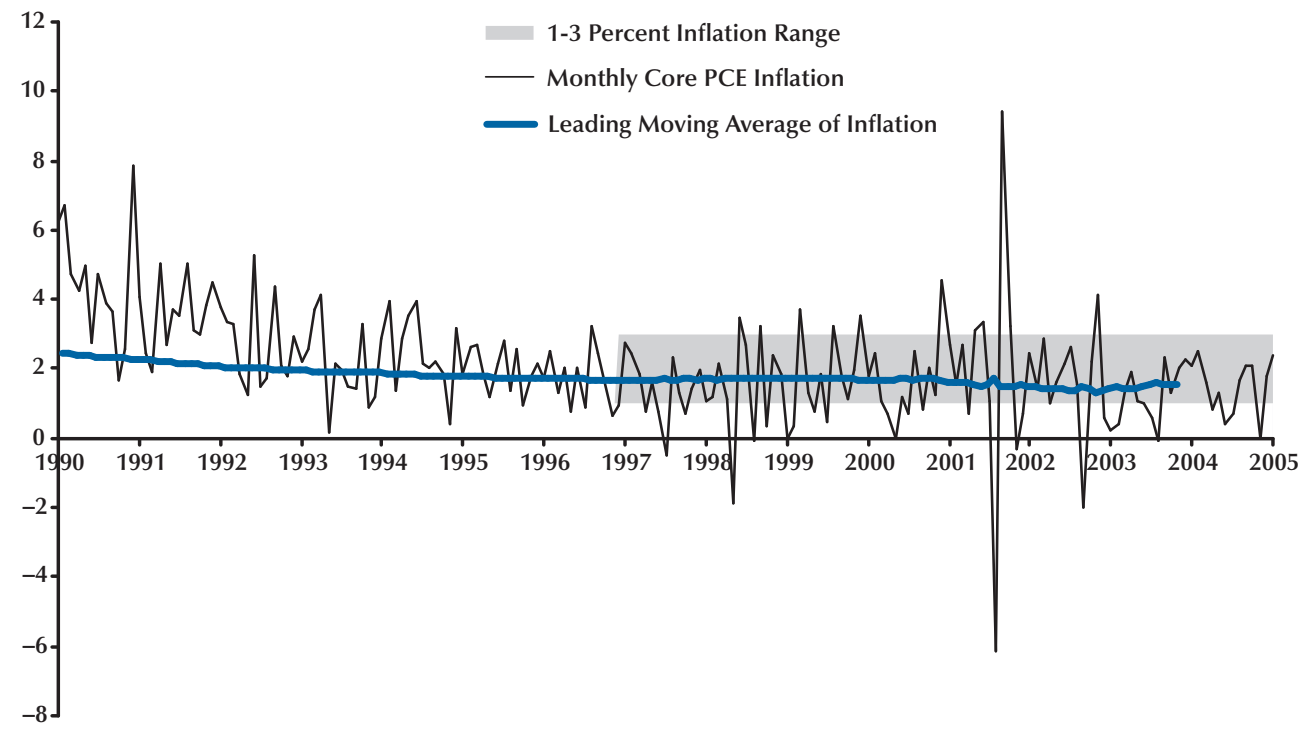

NOTE: CPI for all urban consumers: All items less food and energy.

SOURCE: FRED ${ }^{\circledR}$, Federal Reserve Bank of St. Louis. 
Table 2

Effectiveness of Explicit Numeric Inflation Targeting

\begin{tabular}{|c|c|c|c|c|c|}
\hline Country & $\begin{array}{l}\text { Target range as of } \\
\text { Dec. } 2004(\%)\end{array}$ & $\begin{array}{c}\text { First date for } \\
\text { which target } \\
\text { range is not met }\end{array}$ & $\begin{array}{l}\text { Number of } \\
\text { periods } \\
\text { within range }\end{array}$ & $\begin{array}{l}\text { Moving average } \\
\text { rate of inflation } \\
\text { from Dec. } 2002 \\
\text { to Dec. } 2004(\%)\end{array}$ & $\begin{array}{c}\text { Standardized } \\
\text { deviation } \\
\text { from } \\
\text { moving average }\end{array}$ \\
\hline Australia & $2-3$ & June 2000 & 17 & 2.51 & 0.02 \\
\hline Brazil & $4.5 \pm 2.5$ & Dec. 2003 & 12 & 8.80 & 1.72 \\
\hline Canada & $2 \pm 1$ & Nov. 1992 & 109 & 2.24 & 0.24 \\
\hline Chile & $2-4$ & Nov. 2003 & 13 & 1.76 & -1.24 \\
\hline Colombia & $5-6$ & Dec. 2002 & 24 & 6.17 & 1.34 \\
\hline Czech Republic & $1-3$ & Feb. 2002 & 34 & 1.93 & -0.07 \\
\hline Hungary & $3.5 \pm 1$ & Dec. 2003 & 12 & 5.75 & 2.25 \\
\hline Iceland & $2.5 \pm 1.5$ & $\begin{array}{l}\text { Aug. } 2003 \\
\text { ext date is April 2001) }\end{array}$ & 16 & 3.37 & 0.58 \\
\hline Israel & $1-3$ & Nov. 2003 & 13 & -0.35 & -2.35 \\
\hline Korea & $2.5-3.5$ & $\begin{array}{l}\text { Nov. } 2003 \\
\text { ext date is Nov. 2001) }\end{array}$ & 13 & 2.87 & -0.26 \\
\hline Mexico & $2-4$ & Dec. 2003 & 12 & 4.69 & 1.69 \\
\hline New Zealand & $1-3$ & Never ${ }^{1}$ & 59 & 2.15 & 0.15 \\
\hline Norway $^{2}$ & 2.5 & Never & 45 & 0.85 & - \\
\hline Peru & $2.5 \pm 1$ & Nov. 2003 & 13 & 3.03 & 0.53 \\
\hline Philippines & 4-5 & Dec. 2003 & 12 & 6.38 & 3.76 \\
\hline Poland & $2.5 \pm 1.5$ & Dec. 2003 & 12 & 3.09 & 0.39 \\
\hline South Africa & 3-6 & Feb. 2002 & 34 & 4.25 & -0.17 \\
\hline Sweden & $2 \pm 1$ & Dec. 2003 & 12 & 0.78 & -1.22 \\
\hline Switzerland & $<2$ & Never $^{3}$ & 59 & 0.97 & -0.03 \\
\hline Thailand & $0-3.5$ & Never ${ }^{4}$ & 55 & 0.30 & -0.83 \\
\hline United Kingdom & $2 \pm 1$ & Never 5 & 146 & $1.46^{6}$ & -0.54 \\
\hline
\end{tabular}

NOTE: ${ }^{1}$ Average rate of inflation for New Zealand has never gone outside the range since inflation targeting was adopted (1990).

${ }^{2} \mathrm{No}$ index numbers for CPI-ATE (CPI, adjusted for tax changes and excluding energy products) are available. Average rate of headline $\mathrm{CPI}$ inflation was used instead. Value for average rate of headline CPI inflation has never exceeded $2.5 \%$ since inflation targeting was adopted (2001). ${ }^{3}$ Average rate of inflation for Switzerland has never gone outside the range since inflation targeting was adopted (2000). First date for which the average rate of inflation was outside the range was October 1989 at $2.09 \% .{ }^{4}$ Average rate of inflation for Thailand has never gone outside the range since inflation targeting was adopted (2000). The first date for which the average rate of inflation was outside the range was August 1992 at 3.52\%. ${ }^{5}$ First date for which the average rate of inflation was outside the range was March 1992 at 3.03\% for average rate of RPIX inflation. ${ }^{6}$ Note that in December 2002, the United Kingdom targeted RPIX and not headline $\mathrm{CPI}$. The value for the average rate of inflation of RPIX at that time was $2.6 \%$, still within the target range as of December 2004 . 
Australia also have maintained, for considerable periods, an average rate of inflation within the range currently in effect. (Note that for Australia and New Zealand, data are quarterly and not monthly.) None of these countries has a particularly wide target range. The Czech Republic and South Africa have shorter records of success by this metric, but nevertheless have moderately effective performances. The Czech Republic is notable because the inflation rate there was fairly high when the target was adopted and the moving average of the rate of inflation has fallen outside of the target range only on the low side. Nevertheless, the moving average of Czech headline inflation has been positive for the entire period since it fell below the lower bound of the current target range (in February 2002).

Israel, Peru, and Poland have experienced long-term average inflation below their current target ranges. The short-horizon moving averages for Hungary, Peru, and Poland have exceeded the current target ranges. In Israel, the moving average of the rate of inflation actually went negative in 2002 and 2003. Three countries-Chile, Colombia, and Hungary-have adjusted their targets downward over time, and generally the average inflation rate has fallen below the ranges, consistent with success in moving to the lower inflation targets. Deviations from the target ranges have been symmetric. Other countries, notably Brazil, Mexico, and the Philippines, have consistently missed their target ranges on the high side.

Although averages provide interesting insights into the sustainability of inflation performance, they obscure the marginal performance. A moving average could remain within the target range for a long period of time if, over time, the inflation rate converges toward the midpoint of the range. Alternatively, the same moving average could result if, early in the period, the inflation rate was close to one end point of the target range and, as time progressed, inflation moved close to the opposite edge of the target range. The latter situation could be characterized as "skating on thin ice."

To examine this issue, Table 2 shows the value of the moving average over the two-year period 2003-04 and a standardized deviation of this two- year moving average from the midpoint of the target range that prevailed at the end of 2004. The standardization is constructed by dividing the deviation of the moving average from the midpoint by one-half the difference between the upper and lower endpoints of the target range.

By this metric, the bulk of the inflationtargeting countries have been doing quite well over the past two years. The exceptions are Brazil, Colombia, Hungary, Mexico, and the Philippines (whose average inflation rate over the past two years fell above their target ranges) and Israel and Sweden (whose average inflation rate over the past two years fell below the target ranges).

Our conclusion from these data is that central banks that have announced explicit numeric inflation objectives have been quite effective in achieving the stated inflation stabilization objective.

The FOMC has not adopted this framework, though it is known that on at least three occasions the pros and cons of adopting this approach have been debated around the FOMC table. ${ }^{7}$ Several current participants in the FOMC have stated on the record their preference for an explicit numeric target and given their preferred measures. Included are then-Governor Ben Bernanke, President Jeffrey Lacker of the Federal Reserve Bank of Richmond, President Janet Yellen of the Federal Reserve Bank of San Francisco, and formerPresident Anthony Santomero of the Federal Reserve Bank of Philadelphia. ${ }^{8}$

Then-Governor Bernanke indicated his preferred inflation target is 1 to 2 percent as measured by the core personal consumption price index. ${ }^{9}$ President Lacker has indicated his preference for

7 Transcripts of two of these debates, on January 31, 1995, and July 2, 1996, can be found on the web site of the Board of Governors of the Federal Reserve System: www.federalreserve.gov/fomc/ transcripts/transcripts_1995.htm and www.federalreserve.gov/ fomc/transcripts/transcripts_1996.htm, respectively. A summary of the most recent debate at the February 1, 2005, FOMC meeting is also available on the Board's web site: www.federalreserve.gov/ fomc/minutes/20050202.htm.

8 During the July 1996 FOMC debate on inflation targets, President Gary Stern of the Federal Reserve Bank of Minneapolis indicated that a 2 percent target (in terms of the CPI) would be acceptable to him (FOMC Transcripts, July 2-3, 1996, p. 56). The discussion at that time was not framed in terms of a target point or a target range.

9 See, for instance, Derby (2005). 
a target of 2 percent as measured by the core CPI or 1.5 as measured by the core personal consumption price index; he has also indicated a preference that inflation be kept above 1 percent (Lacker, 2005). President Yellen has indicated a preference for a target of 1.5 percent as measured by the core personal consumption price index, with a range of about \pm 1 percent (Reuters News, 2005). FormerPresident Santomero indicated his preference for a target range of 1 to 3 percent as measured by a 12-month moving-average rate of change in the core personal consumption price index (AFX Asia, 2004). Other current participants at FOMC meetings, including Vice Chairman Donald Kohn (2005), have indicated that they do not prefer an explicit numeric inflation objective. President William Poole has stated that he believes "ambiguity with respect to the Fed's inflation and employment objectives is not large and is not the main problem the Fed faces with its communication policies" (Poole, 2005b).

Differences of opinion among FOMC participants notwithstanding, in May 2003 the press release following the FOMC meeting indicated that "the probability of an unwelcome substantial fall in inflation, though minor, exceeds that of a pickup in inflation from its already low level. ${ }^{10}$ The minutes of that FOMC meeting (FOMC Minutes, May 6, 2003) indicate the rationale for this statement:

\section{Members commented that substantial addi- tional disinflation would be unwelcome because of the likely negative effects on eco- nomic activity and the functioning of financial institutions and markets, and the increased difficulty of conducting an effective monetary policy, at least potentially in the event the economy was subjected to adverse shocks. Members also agreed that there was only a remote possibility that the process of disinfla- tion would cumulate to the point of a decline for an extended period in the general price level. ${ }^{11}$}

At that time, core personal consumption inflation was measured in the neighborhood of

\footnotetext{
10 See www.federalreserve.gov/boarddocs/press/monetary/2003/ 20030506/default.htm.

${ }^{11}$ See www.federalreserve.gov/fomc/minutes/20030506/htm.
}

1 percent. Although the FOMC has never stated a numeric inflation objective, individual FOMC participants have expressed preferences for both the core CPI and core personal consumption price index; they have typically indicated values for core CPI inflation one-half percent above those for the core personal consumption inflation rate. It seems reasonable to conclude that the FOMC has a lower bound of an acceptable medium-term rate of inflation in the neighborhood of 1 percent for the core personal consumption inflation rate and perhaps 1.5 percent for the core CPI inflation rate.

Former-Governor Larry Meyer (2004) is also on record in favor of an explicit numeric inflation objective. However, his position is that the "dual mandate" inherent in the Federal Reserve Act differentiates the U.S. environment from that of other inflation-targeting central banks that operate under a "hierarchical mandate." Meyer defines a hierarchical mandate as an environment "in which price stability is identified as the principal objective, and central banks are restricted from pursuing other objectives unless price stability has been achieved" (p. 151). He contrasts this with the "dual mandate," where "monetary policy is directed at promoting both full employment and price stability with no priority expressed, and with the central bank responsible for balancing these objectives in the short run" (p. 151). It is our opinion that Meyer's view does not allow for the effectiveness of monetary policy to vary in the long and short runs. In terms of long-run objectives, central banks must necessarily operate under a hierarchical mandate, given the consensus view of monetary policy that policymakers are not presented a long-run tradeoff between inflation and real output. Indeed, in specifying a policy rule, whether an instrument or target rule, the exercise of determining how much weight to place on short-run movements in inflation versus short-run movements in real output is conditioned on the prespecification of the long-run inflation target $\left(\pi^{*}\right)$. In this sense, any central bank seeking to operate in such a monetary policy framework has to be hierarchical: First it must specify its long-run inflation objective and then, and only then, can it set its preferred (or optimal) weights 
for short-run fluctuations. ${ }^{12}$ The choice of weights could be such that the central bank follows a hierarchical mandate in both the long and short runs; however, there is nothing to preclude pursuing a dual goal, with a short-run mandate nested within a hierarchical long-run mandate. It is likely that most, if not all, central banks that have adopted an explicit inflation target pursue that objective within a nested hierarchical/dual structure.

Panels A and B of Figure 23 show the core CPI inflation and core personal consumption price inflation for the United States; the leading moving average from each of the dates since January 1990 until the end of 2004 are also shown. ${ }^{13}$ The shaded area, from 1 to 3 percent in core CPI inflation, appears to encompass the preferences of the FOMC participants who have spoken out in favor of an explicit numeric inflation objective. The leading moving-average rate of core CPI inflation in the United States bottomed out in August 2002 at a value of 1.64 percent (annual rate). The corresponding date and value for core personal consumption price inflation are December 2002 and 1.28 percent, which appear to be close to the bottom of the FOMC's implicit acceptable range of inflation. On the other end of the scale, the leading moving-average rate of core CPI inflation has been below the 3 percent level since March 1991, whereas that for personal consumption price inflation has been below the 3 percent level since March 1987. These are comparable to the best performance of the inflation-targeting central banks against their announced targets. Accordingly, it cannot be claimed that an explicit numeric inflation target is a necessary condition to produce low and stable rates of inflation for an extended period. The question, which will not be answered unless inflation pressures build in the future, is whether in the absence of a public numeric inflation objective the institutional commitment exists to take potentially unpopular policy actions to resist upward creep in inflation.

\footnotetext{
${ }^{12}$ See also Svensson (2004).

${ }^{13}$ Relative to the end of 2004, the line indicates a trailing moving average of inflation back to the date indicated.
}

\section{HOW EFFECTIVE ARE CENTRAL BANKS AT SHORT-RUN (OUTPUT) STABILIZATION?}

The evidence on the effectiveness of monetary policy as a short-run stabilization device is problematic. As Poole (2005b) has noted,

\begin{abstract}
[t]he only certainty is that the effect of policy actions on real variables eventually dissipates. "Eventually" may cover a period of several years, and may be longer in some circumstances than others. It is worth noting that these hedges on my part reflect ignorance-mine and the profession's-and not obfuscations. We just don't have precise estimates of the magnitudes and durations of effects of monetary policy on real variables.
\end{abstract}

Our objective here is to examine why a definitive answer to this question remains so illusive. On one hand there is "case study" evidence supporting the idea that monetary policy does affect output fluctuations in the short run. The most prominent evidence from such studies highlights the contractionary effects of monetary policy. On the other hand, there are volumes of VAR analyses that fail to determine a major role for monetary policy in short-run stabilization.

The best known, though not uncontested, case-study analysis of the short-run response of real activity to monetary policy is Friedman and Schwartz's (1963) monetary history. They argue that the Federal Reserve put the "great" in the Great Contraction:

The monetary character of the contraction changed drastically in late 1930, when several large bank failures led to the first of what were to prove a series of liquidity crises involving runs on banks and bank failures on a scale unprecedented in our history...

The drastic decline in the stock of money and the occurrence of a banking panic of unprecedented severity did not reflect the absence of power on the part of the Reserve System to prevent them. Throughout the contraction, the System had ample powers to cut short the tragic process of monetary deflation and banking collapse. Had it used those powers effectively in late 1930 or even in early or mid-1931, 
the successive liquidity crises that in retrospect are the distinctive feature of the contraction could almost certainly have been prevented and the stock of money kept from declining, or indeed, increased to any desired extent. Such action would have eased the severity of the contraction and very likely would have brought it to an end at a much earlier date. (pp. 10-11)

Romer and Romer (1989) construct case studies of six episodes from World War II through 1979 in which they believe that the Fed deliberately took action to induce a recession to reduce inflation. They conclude that the evidence supports the hypothesis that the monetary policy actions had a significant negative effect on real output in all of these instances. Case studies such as these address the qualitative question of whether monetary policy has an effect on real output; they do not address the question of the magnitude of the output response to a change in policy.

The final experience that is widely cited as evidence of a contractionary effect of monetary policy is the U.S. experience in 1979-83: the socalled "Volcker disinflation." This period is marked by two separate recessions: January-July 1980 and July 1981-November 1982. The first recession followed closely the introduction of the "new operating procedures" in October 1979 and an increase of 6 percent in the federal funds rate. ${ }^{14}$ Note that the increase in the funds rate was not directly targeted by the Fed under the "new operating procedures." Furthermore, the impact of the monetary policy action in 1980 is confounded with the introduction of credit controls by the Carter administration in March 1980. ${ }^{15}$

Goodfriend (2005) maintains that the recession of 1981-82 was the direct consequence of monetary policy directed at disinflation:

The lesson of 1980 was that the Fed could not restore credibility for low inflation if it continued to utilize interest rate policy to stabilize

\footnotetext{
${ }^{14}$ For an analysis of the environment that led to the introduction of the "new operating procedures" and the objectives that the Volcker Fed sought to achieve with this innovation, see Lindsey, Orphanides, and Rasche (2005).

${ }^{15}$ See Schreft (1990).
}

the output gap...As measured by personal consumption expenditures (PCE) inflation, which was about 10 percent in Q1 1981, real short-term interest rates were then a very high 9 percent. Not surprisingly, the aggressive policy tightening began to take hold by midyear. (pp. 316-17)

Certainly, the home building industry in the United States regarded the collapse of housing construction during both recessions as the direct responsibility of the Volcker Fed, as evidenced by the numerous complaints delivered to the Board of Governors written on $2 \times 4$ s. The housing construction industry in the United States showed highly cyclical fluctuations through the recession of 1990-91 (see Figure 24), and concerns about the sensitivity of this industry to monetary policy actions had been the focus of discussion at least since the early 1960s. ${ }^{16}$

Housing starts and housing construction behaved very differently in the 2001 recession than in prior postwar recessions: No slowdown is obvious. Admittedly, this cyclical slowdown was very mild, at least as measured in terms of real output growth. Yet this raises the question of whether cyclical fluctuations in housing should be cited as universal evidence of an impact of monetary policy on short-run fluctuations. ${ }^{17}$

One legacy of the Great Depression in the United States has been the use of price controls on bank deposits-so-called Reg Q ceilings. In 1966 these controls were extended to liabilities of thrift institutions that, at the time, were the principal source of mortgage financing. Cyclical fluctuations in interest rates had a major impact on the availability of mortgage financing during this period. By the mid-1980s these price controls had been removed, but by that time (economic) insolvency was widespread among thrift institutions. The resolution of the crisis in the housing finance industry continued through the recession of 1990-91. Hence, it may be more appropriate to argue that the interaction of monetary policy with

\footnotetext{
${ }^{16}$ See, for example, Federal Reserve Bank of Boston (1970) and Grebler and Maisel (1963).

${ }^{17}$ Stock and Watson (2003) note the large decline in the volatility of residential construction (though not nonresidential construction) in the United States since the mid-1980s (p. 39).
} 


\section{Figure 24}

\section{U.S. Housing Starts: Annual Rates}

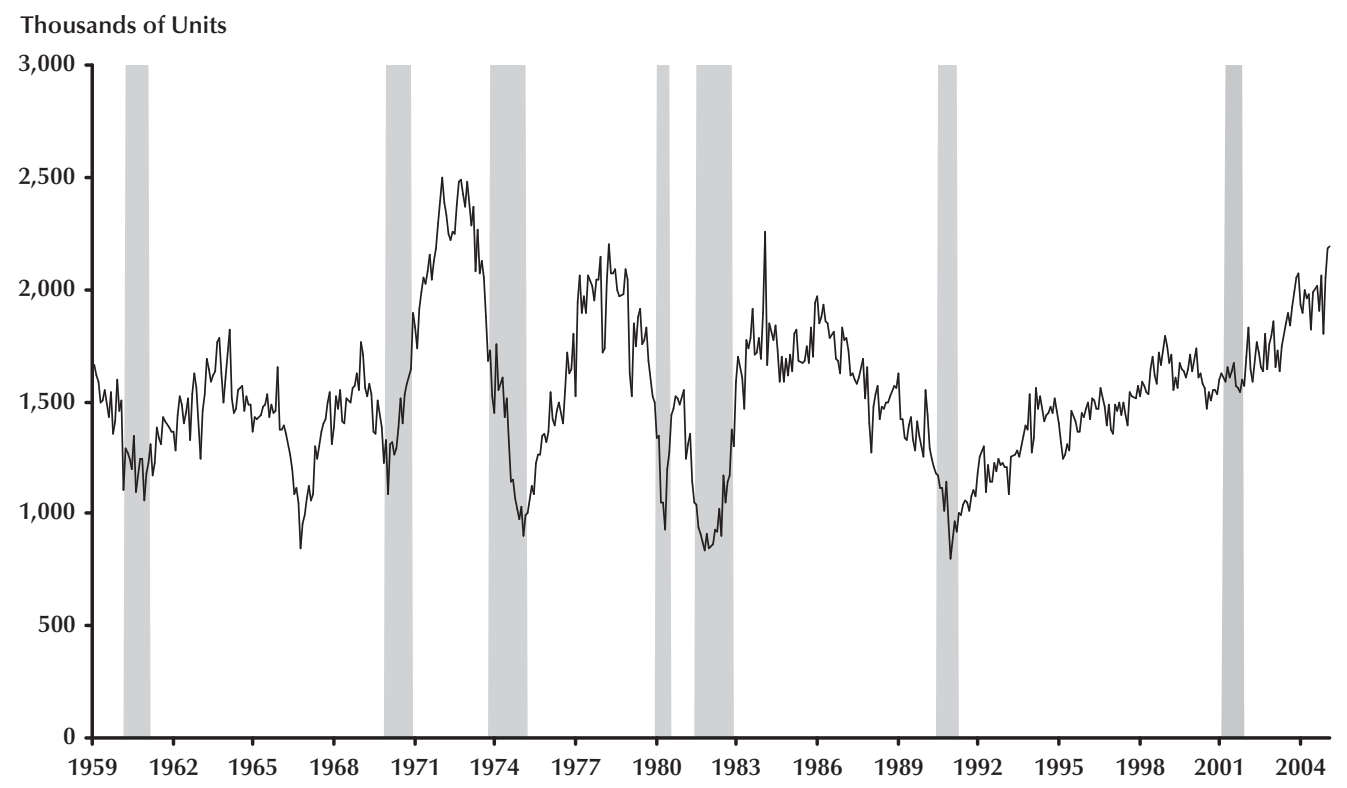

NOTE: Shaded bars indicate recessions.

the system of deposit price controls produced a unique environment that supported a cyclical response of the economy to monetary policy actions. In the current U.S. environment, where mortgage securitization has become the rule and specialized deposit intermediaries have ceased to be significant players in mortgage finance, a traditional argument for the transmission of monetary policy may be more tenuous.

Econometric models provide alternative evidence on the effectiveness of monetary policy in influencing the short-run behavior of real output. Over the past 25 years, since the publication of Sims's (1980) classic article, literally hundreds, perhaps thousands, of econometric studies in vector autocorrelation (VAR) frameworks have sought to address this question. We believe that few people would argue that research in this framework has provided conclusive evidence to support the hypothesis that monetary policy has strong short-run effects on real output fluctuations. Christiano, Eichenbaum, and Evans (1999) summarize their extensive overview of this literature:
"[V]iewed across both sets of identification strategies that we have discussed, there is a great deal of uncertainty about the importance of monetary policy shocks in aggregate fluctuations" (p. 127) and "there is agreement that monetary policy shocks account for only a very modest percentage of the volatility of aggregate output; they account for even less of the movements in the aggregate price level”(p. 71). But if a consensus from case studies of historical episodes is that there are substantial effects, the question is how to reconcile the apparently conflicting evidence. An early assessment of the VAR type of study is provided by Cagan (1989):

If we accept the bulk of historical evidence as confirming the important monetary effects on the real economy, contrary findings cannot be fully valid. And, if such contrary evidence is not valid, what kind of evidence in monetary research is acceptable and convincing? (p. 119)

The VAR seems to me to be hopelessly unreliable and low in power to detect monetary effects of the kind we are looking for and 
believe, from other kinds of evidence, to exist. (p. 127)

In the approximately 15 years since Cagan posed this question, analysts have become much more aware of the limitations of VAR analyses. It is now well understood that the VAR approach does not solve the fundamental econometric problem of identification. The VARs that are readily estimated using standard econometric software are no more than reduced-form models. ${ }^{18}$ Indeed, there is substantial risk of misspecification as a result of omitted variables, given the limits on the dimensionality of the typical VAR that is imposed by the available time span of macroeconomic data series.

In the formative years of VAR analysis (say 1980-86) the typical approach was to "rotate and orthogonalize shocks" by computing a Cholesky decomposition of the covariance matrix of the estimated VAR residuals and to assume that one of the resulting "shocks," frequently that associated with a short-term interest rate, represented the monetary policy innovation-the unpredictable component of monetary policy. Analyses of the effectiveness of monetary policy were constructed from impulse response functions and variance decompositions with respect to this "monetary shock."

Gradually, it became recognized that "recursiveness and orthogonalization" is the imposition of a particular set of identifying restrictions-a triangular Wold causal chain structure. ${ }^{19}$ This approach to identification was widely rejected by the econometrics establishment when initially proposed in the 1960s. Starting in the mid-1980s, alternative restrictions for identification of "structural VARs" (SVARs) appeared in the literature. ${ }^{20}$ Generally the SVAR framework has maintained the identifying restrictions that the shocks in the "economic model" are independent and has found the additional required restrictions among the only available alternatives: constraints on impact or steady-state multipliers of the SVAR

\footnotetext{
${ }^{18}$ For an extensive discussion of the identification problem in VAR models, see Christiano, Eichenbaum, and Evans (1999, Section 2).

${ }^{19}$ See Wold (1954 and 1960).

${ }^{20}$ See, for example, Sims (1986) and Bernanke (1986).
}

or exclusion restrictions on the slope coefficients among contemporaneous variables or steadystate relationships in the SVAR.

Steady-state identifying restrictions are those for which accepted theory provides the most insight. Such restrictions may provide information on the dynamics of a real output response to a monetary policy shock that produces a permanent change in the inflation rate (assuming that inflation is approximately a nonstationary variable during the sample period). This is facilitated by received macroeconomic theories that suggest only monetary shocks can produce sustained changes in inflation. In an economy where the central bank focuses on a rule for an interest rate target that responds to deviations from a desired rate of inflation and other variables such as output gaps, such monetary shocks occur only when there is a change in the inflation target. ${ }^{21}$ This does not get to the question of the effectiveness of monetary policy for short-run output stabilization. Here, the issue is how real output responds to monetary shocks that cause transitory fluctuations in the inflation rate (i.e., changes in the price level).

Unfortunately, received macroeconomic theories suggest that shocks from many nonmonetary sources can have a permanent effect on the price level. Examples include fiscal policy shocks, energy price shocks, productivity shocks, and terms-of-trade shocks. In such economic structures, restrictions on impact multipliers are hard to justify and sufficient restrictions on slope coefficients among the contemporaneous variables in the VAR to identify the desired monetary shock are problematic. This concern is echoed in Romer and Romer (1989, p. 121):

The reason that purely statistical tests, such as regressions of output on money, studies of the effects of "anticipated" and "unanticipated" money, and vector autoregressions, probably have not played a crucial role in forming most economists' views about the real effects of monetary disturbances is that such procedures cannot persuasively identify the direction of causation.

\footnotetext{
${ }^{21}$ This conclusion should hold regardless of whether the central bank pursues an instrument rule or a target rule.
} 
Identification of the effectiveness of monetary policy to stabilize output fluctuation is further complicated by a lack of transparency and likely a lack of stationarity in the rule-like behavior of central banks. There is an ongoing debate about whether FOMC behavior over a long period can be characterized by a common rule-like specification. Romer and Romer (2002a,b) argue that the actions of the FOMC in the 1950s and in the 1980-90s were similar in their rule-like characteristics, but that during the 1960s and 70s a different "regime" was in place. Orphanides (2001 and 2002) and Orphanides and van Norden (2002) argue that, when judged in terms of real-time data, the rule-like behavior of the FOMC in the 1960s and 1970s is consistent with behavior in the 1980s and 1990s. They conclude that the Great Inflation did not result from bad policy, but from applying reasonable policy without recognition of and adjustment for biased measurements of "potential output." Either view of the 1960 and 1970s poses a challenge to the standard approach of identifying monetary shocks in SVAR structures.

Beyond the arguments about the specification of monetary policy during the Great Inflation, there are other concerns that at least occasionally dominate central bankers' discussions of policy objectives. Such concerns at a minimum contaminate efforts to identify policy rules with measurement error and likely also contaminate the assumed identifying restrictions.

For the FOMC, there are at least four incidents in the past 20 years (documented in the published record of FOMC minutes and transcripts) in which concerns about financial stability dominated policy decisions and policy actions were driven by issues in addition to inflation or output stabilization. These incidents include the stock market collapse in October 1987, the Asian crisis/Russian default in August-October 1998, Y2K in late 1999, and the 9/11 tragedy in September 2001. Some analysts add the credit crunch/financial headwinds concern in 1990-93 to this list. ${ }^{22}$

According to the unofficial staff interpretations of FOMC policy changes compiled by Thornton and Wheelock (2000), the expected funds rate was

\footnotetext{
${ }^{22}$ See, for example, Romer and Romer (2002b, p. 68).
}

decreased by 37.5 basis points on October 23, 1987 , and by an additional 12.5 to 25 basis points on October 28, 1987, in response to the stock market crash. This interrupted the succession of increases in the expected funds rate that had started on January 15, 1987. Increases in the expected funds rate were not resumed until March 29, 1988, roughly six months after the crash. During a conference call on October 20, 1987, Chairman Greenspan noted,

I think we're playing it on a day-to-day basis. And in a crisis environment. I suspect we shouldn't really focus on longer-term policy questions until we get beyond this immediate period of chaos. (FOMC Transcripts, conference call, October 20, 1987, p. 1)

On September 29, 1998, the FOMC reduced the funds rate target by 25 basis points. This was followed by a two additional reductions of 25 basis points on October 15 and November 17. Chairman Greenspan noted the following at the February 1999 FOMC meeting:
I have not heard it argued specifically, but our 75 basis point action last fall was directed at countering a freezing-up of financial markets, which constituted a demonstrable threat to the stability of our economy, and arguably we have largely succeeded. It is true that one can still observe some residual impact of the liquidity problems that we have experienced, with yields on junk bonds remaining significantly above Treasuries and even obligations rated A and AA still running spreads against Treasuries that we haven't seen for a very long time. If it is correct that we have succeeded, then one could argue that we ought to reverse at least part of our easing moves. (FOMC Transcripts,
February 2-3, 1999, p. 104)

The funds rate target established in November was maintained until the FOMC meeting in June 1999, though no argument was made that financial markets remained unsettled after November.

On December 21, 1999, the FOMC press release noted that the funds rate target was kept unchanged, in spite of

the possibility that over time increases in demand will continue to exceed the growth in potential supply, even after taking account 


\section{Rasche and Williams}

of the remarkable rise in productivity growth. (FOMC Press Release, December 21, 1999)

The maintenance of the existing target funds rate was explained by concerns about the century date change:

Nonetheless, in light of market uncertainties associated with the century date change, the Committee decided to adopt a symmetric directive in order to indicate that the focus of policy in the intermeeting period must be ensuring a smooth transition into the Year 2000. (FOMC Press Release, December 21, 1999)

On September 17, 2001, the FOMC press release noted that the funds rate target was reduced 50 basis points in response to the uncertainty about financial market conditions in light of the terrorist attack on the World Trade Center:

The Federal Reserve will continue to supply unusually large volumes of liquidity to the financial markets, as needed, until more normal market functioning is restored. (FOMC Press Release, September 17, 2001)

On the same date, Chairman Greenspan noted:

It's clear that the events of last week, at a minimum, have created a heightened degree of fear and uncertainty that is placing considerable downward pressure on asset prices, increasing the probability of an asset price deflation, with its obvious impact on the economy. (FOMC Transcripts, conference call, September 17, 2001)

It is worth noting that, while in real time FOMC participants were concerned about significant weakness in economic activity in the fourth quarter of 2001, the current estimate is that gross domestic product (GDP) grew at a positive 1.6 percent annual rate in that quarter.

Our conclusion from these questions is that considerable care and additional research is required to ensure that a valid identified model of the economy is constructed to enable us to draw inferences about the effectiveness of monetary policy as a tool for short-run stabilization of an economy. The number of issues that remain to be addressed suggests that we are a long way from a definitive answer.
If the objective of a well-identified model is achieved, then how should it be used to address the question of the effectiveness of monetary policy? Impulse response functions and variance decompositions that investigate the response to a monetary shock may not be the most informative analyses. These address only how the economy responds to the unpredictable component of monetary policy - the deviations from rule-like behavior. Cagan (1989, p. 135) complained that in the VAR analysis available at the time, the impact of such residuals was so small as to be implausible:

By removing all serial and cross correlations from economic series, VAR reduces them to exogenous movements and looks for correlation between these movements in each pair of series. But these exogenous movements are little more that isolated blips in the series, which in monetary growth have little effect on GNP. The financial system filters out the effect on monetary blips. Only changes in monetary growth that are maintained for an extended period of time affect business activity These extended changes in monetary growth, however, exhibit serial correlation and, despite their variable lags in affecting output and prices, tend to be correlated with cyclical movements in other economic variables. The VAR accordingly eliminates the correlated movements in money as endogenous to the economic system. Thus does this technique give new meaning to the old cliché of "throwing the baby out with the bathwater."

An alternative investigation is to vary the parameters in the equation of the identified economic model that characterize the rule-like behavior of the monetary authorities. The question then becomes not how effective monetary policy has been in stabilizing the economy under the historical characterization of policy, but how effective it could be with alternative rule-like behaviors. Christiano, Eichenbaum, and Evans (1999, pp. 134-46) argue that with VAR models this type of analysis may be difficult, because identification of monetary policy shocks is not sufficient to identify the historical policy rule pursued by the central bank. The answer to the question of how effective monetary policy could be in short-run 
stabilization likely depends on the nature of the shocks that are assumed to hit the economy and, at least for some shocks, the relative tolerance for short-run inflation volatility versus output volatility.

Finally, has increased transparency and accountability of monetary authorities led to increased economic stability? This question has been raised in several contexts. First, some analysts have argued that the "Great Moderation" since approximately 1983 is substantially due to better monetary policy and improved transparency. Stock and Watson (2003, p. 29) use three different econometric models of the U.S. economy and replace their estimate of a post-1984 monetary policy rule with their estimate of a pre1979 monetary policy rule. They conclude from these experiments that the models "all suggest that improved monetary control brought inflation under control, but accounts for only a small fraction-among the models fit to the United States data, less than 10 percent-of the reduction in output volatility."

Other analysts argue that improved transparency and accountability of central banks anchor long-term inflation expectations more firmly, thus giving central banks more latitude to pursue short-run stabilization objectives. Support for this argument requires two kinds of research: (i) What evidence would support the hypothesis that long-term inflation expectations are less variable and (ii) has the rule-like behavior of any central bank become more aggressive in reacting to short-term fluctuations of output? Levin, Natalucci, and Piger (2004) provide some evidence on both of these issues by comparing inflation-targeting industrial countries with industrial countries that do not announce inflation targets; they conclude (p. 75) that inflation targeting in these countries has "played a role in anchoring inflation expectations and in reducing inflation persistence."

Chairman Greenspan early on argued that a low and stable inflation environment contributed to the higher rate of productivity growth in the United States after 1995:

Given these real-world uncertainties, it is important for policymakers to be as explicit as possible about not only the central bank's long-run inflation objective but also about its short-run policy objectives. The more ambiguous policymakers are about these objectives, the more difficult it will be for the public to differentiate policy actions that may reflect a change in the central bank's long-run inflation objective from actions intended only to offset the effects of real shocks on economic activity ...Implicit in that argument, if we are to move toward price stability, is that the process in and of itself induces an acceleration of productivity. (FOMC Transcripts, July 2-3, 1996, p. 47)

It is not that low or stable prices are an environment that is conducive to capital investment to reduce costs, but rather that it is an environment that forces productivity enhancements. It forces people who want to stay in business to take those actions-such as cutting down the size of the cafeteria, reducing overtime, and taking away managers' drivers-that they did not want to take before in the ordinary course of business in a modest inflationary environment because it was easier then just to raise prices to maintain margins. If you force the price level down, you induce real reallocations of resources because to stay in business firms have to achieve real as distinct from nominal efficiencies. (FOMC Transcripts, July 2-3, 1996, p. 67)

This is an intriguing hypothesis that is difficult to investigate, given the limited understanding and theory of the determinants of productivity growth. Unfortunately, it is difficult to reconcile this hypothesis with the apparent uniqueness of the U.S. experience with the "productivity boom" in the face of almost worldwide low and stable inflation over the past decade.

\section{PROBLEMS IN THE IMPLEMENTATION OF SHORT- RUN STABILIZATION POLICY}

One important issue for the implementation of short-run stabilization policy that did not receive much attention for a considerable period of time is the inherent uncertainty of the environment in which central bankers make decisions. 
There are several dimensions to this uncertainty: (i) lack of accurate information about the contemporary state of the economy, (ii) inability to forecast accurately the future path of the economy, and (iii) lack of accurate information about how policy actions affect the economy.

Two problems face central bankers (and policymakers in general) in assessing the need for a short-run stabilization action: lags in the availability of data and measurement error in preliminary data.

In the United States, major economic statistics are available at either monthly or quarterly frequency, usually with an initial publication lag of a month or two. In other countries, comparable data may be measured at lower frequency and with longer publication lags. Consequently, most formal statistical data that are available for policy deliberations are "stale." In the FOMC process, such data are supplemented by anecdotal data from the various Federal Reserve Districts. ${ }^{23}$ The latter data are not collected from scientific surveys, and the number of respondents surveyed is small. Hence, there is a danger of inappropriately extrapolating from the small environment to the macroeconomy. Nevertheless, such reports can give insights into and reduce, though not eliminate, uncertainty about emerging trends.

The second problem, measurement error, is well known; but until recently, it did not receive much attention, probably because it has been regarded as a mundane problem and research into it is unlikely to receive much attention. In appears that, recently, attitudes have been changing. Research using real-time data has become more fashionable. Some of this research (Orphanides, 2001 and 2002) alleges that the principal culprit in the Great Inflation in the United States was systematic bias in the real-time assessment of "potential output" and the "output gap" in FOMC deliberations. Nevertheless, formal consideration of measurement error in forecasting models, whether constructed by private sector entities or by the staff of policy agencies, remains underdeveloped, even though the econometric methodology is well understood. The paucity of

${ }^{23}$ See, for example, Poole (2002). readily accessible vintage data may contribute to this problem. ${ }^{24}$

An additional issue is the limited accuracy in the forecasts or projections that are available to monetary policymakers. Absent instantaneous reaction of the economy to policy actions, effective stabilization actions require an assessment of the future state of the economy. Gavin and Mandal (2001) found the accuracy of the forecasts by FOMC participants as recorded in monetary policy reports from 1983 through 1994 for real output growth are comparable to those of private forecasters (e.g., Blue Chip forecasters). ${ }^{25}$ However, the root-mean-squared forecast error at 12- and 18-month horizons was roughly 1 percent (at annualized rates.) At a 6-month horizon the forecast error was 0.75 percent. In a subsequent analysis, Gavin and Mandal (2003) extended the sample of forecasts to 1979-2001. For this longer sample, they found that the root-mean-squared forecast errors at the 12- and 18-month horizons were 1.32 and 1.59 percent, respectively. The same statistic at a 6-month forecast horizon was only slightly less than 1 percent. ${ }^{26}$ This forecast (in)accuracy suggests that variations in real output growth, from recessions to rapid expansions, cannot be reliably distinguished on a horizon as short as a year.

The projection accuracy for real output of the Reserve Bank of New Zealand (RBNZ) appears to be comparable to that of the participants in the FOMC. ${ }^{27}$ Root-mean-squared projection errors of

\footnotetext{
${ }^{24}$ For the United States, a limited amount of vintage data has been reconstructed by the research staff of the Federal Reserve Bank of Philadelphia. Complete archives of the FRED ${ }^{\circledR}$ data base have been preserved since the web version of this service was introduced in 1996 at least at monthly intervals and since 1999 at weekly intervals. A new data service (ArchivaL FRED, i.e., ALFRED ${ }^{\circledR}$ ) has been implemented by the Research Division of the Federal Reserve Bank of St. Louis. ALFRED allows the user to retrieve a data list that is indexed with an "as of" vintage date. Over time, vintage data that was preserved on hard copy of National Economic Trends and Monetary Trends will be added to this archive.

${ }^{25}$ Gavin and Mandal (2001, Table 2): Forecasts are fourth-quarter over fourth-quarter growth rates.

${ }^{26}$ Gavin and Mandal (2003, Table 1): Forecasts are fourth-quarter over fourth-quarter growth rates.

${ }^{27}$ See Reserve Bank of New Zealand's "The Projection Process and Accuracy of the RBNZ Projections"; www.rbnz.govt.nz/monpol/ review/0096577.html.
} 
the RBNZ are reported as 1 percent at a 1-quarter horizon and 1.5 percent at a 1-year horizon.

The Bank of England publishes estimates of the "uncertainty associated with its numeric projections of inflation and GDP growth" with each of its Inflation Reports. ${ }^{28}$ At the 1-year projection horizon conditioned on market interest rate expectations, the reported uncertainty measure is 0.76 percent; at the 2-year horizon it is 1.0 percent; and at the 3-year horizon it is 1.10 percent. These values are on the order of 50 percent of the root-mean-squared error of the RBNZ and FOMC projections at comparable horizons, but still suggest substantial uncertainty relative to business cycle fluctuations in real GDP. Other inflation targeting central banks also make public projections of real output growth, though this information does not appear to have a long history and we have not found any other analyses of the performance of these projections. ${ }^{29}$

The final problem is the paucity of accurate information about the dynamic effects of policy actions. Specifically, received macroeconomic theories generally provide little insight into dynamic structures. This is reflected in the VAR paradigm that eschews any restrictions on dynamics.

One perspective, associated with Milton Friedman, is that lags in the impact of monetary policy are "long and variable." Another perspective is derived from impulse response functions of econometric models, including VAR specifications. In many such models, the effect of a shock to the monetary policy variable is constrained to be zero as part of the identifying restrictions imposed on the data. In such models, a typical response pattern is that several quarters elapse before a significant response of real output builds

\footnotetext{
${ }^{28}$ The recent estimates are in the "Numerical Parameters of Inflation Report Probability Distributions, February 2005”;

www.bankofengland.co.uk/publications/inflationreport/index.htm. This report indicates that the uncertainty measure is the standard deviation of the forecast error in those cases where the distribution of forecast errors is symmetric.

${ }^{29}$ We have found quantitative projections/forecasts of real output in published inflation/monetary reports of the central banks of Chile, Hungary, Iceland, Israel, Korea, Mexico, Norway, Peru, Sweden, and the United Kingdom. Undoubtedly, we have missed some reports and we have not completed a tabulation of all published estimates.
}

up, and then this response dissipates over 12 to 18 months. ${ }^{30}$ In general, estimated confidence intervals around the impulse response functions are quite wide. This leaves a policymaker interested in short-run stabilization with a difficult and unfortunate dilemma: The impact of a policy action at any horizon is highly uncertain, and the horizon over which any policy action is most likely to have a major impact is one where the future is not predicted with any precision.

\section{CONCLUSION}

Several conclusions seem warranted. First, inflation-targeting central banks appear to have an admirable record of consistently hitting targets on a medium-run horizon. However, it is not clear what the marginal contribution of inflation targeting beyond a credible commitment to price stability is, because the Federal Reserve, which eschews an inflation-targeting framework, has accumulated a comparable record of low and stable inflation.

Second, it is not clear what will happen to low and stable inflation if "bad shocks" are realized and the going gets tough. "Good luck" in the form of a decade or two of relatively mild shocks cannot be ruled out as a significant environmental factor during the inflation-targeting period (see Stock and Watson, 2003, pp. 46-47.)

Finally, the case for consistently effective short-run monetary stabilization policies is problematic-there are just too many dimensions to uncertainty in the environment in which central banks operate.

\section{REFERENCES}

AFX Asia. "Santomero: Fed Should Adopt Explicit Inflation Target." October 4, 2004.

Anderson, Leonall C. and Carlson, Keith. "A Monetarist Model for Economic Stabilization.” Federal Reserve Bank of St. Louis Review, April 1970, 52(4), pp. 7-25.

\footnotetext{
${ }^{30}$ Impulse response functions that are typical of those derived from VAR analysis can be found in Christiano, Eichenbaum, and Evans (1999, Figures 2 and 4).
} 
Anderson, Leonall C. and Jordan, Jerry L. "Monetary and Fiscal Actions: A Test of Their Relative Importance in Economic Stabilization.” Federal Reserve Bank of St. Louis Review, November 1968, 50(11), pp. 11-24.

Bernanke, Ben S. "Alternative Explanations of the Money-Income Correlation." Carnegie-Rochester Conference Series on Public Policy, Autumn 1986, 25, pp. 49-99.

Brunner, Karl and Meltzer, Allan H. "What Did We Learn from the Monetary Experience of the United States in the Great Depression?" Canadian Journal of Economics, May 1968, 1(2), pp. 324-48; reprinted in A.H. Meltzer, Money, Credit and Policy.

Northampton: Edward Elgar, 1995, pp. 104-18.

Cagan, Phillip. "Money-Income Causality—A Critical Review of the Literature Since A Monetary History," in M.D. Bordo, ed., Money, History and International Finance: Essays in Honor of Anna J. Schwartz. Chicago: University of Chicago Press, 1989, pp. 117-51.

Calvo, Guillermo A. "Staggered Prices in a UtilityMaximizing Framework." Journal of Monetary Economics, September 1983, 12(3), pp. 383-98.

Christiano, Lawrence J.; Eichenbaum, Martin and Evans, Charles L. "Monetary Policy Shocks: What Have We Learned and to What End?" in J.B. Taylor and M. Woodford, eds., Handbook of Macroeconomics. Volume 1A. Amsterdam: Elsevier, 1999, pp. 65-148.

Clarida, Richard; Galí, Jordi and Gertler, Mark. "The Science of Monetary Policy: A New Keynesian Perspective." Journal of Economic Literature, December 1999, 37(4), pp. 1661-707.

Council of Economic Advisers. Economic Report of the President. Washington, DC: 1962, 1963, 1975.

Derby, Michael. Dow Jones Commodity Wire report of Ben S. Bernanke's remarks at Stanford University, February 11, 2005.

Fischer, Stanley. "Long-Term Contracts, Rational Expectations, and the Optimal Money Supply Rule."
Journal of Political Economy, February 1977, 85(1), pp. 191-205.

Federal Open Market Committee. Transcripts, Minutes, and Press Releases. Various dates.

Federal Reserve Bank of Boston. Housing and Monetary Policy. Conference Series, Number 4, October 1970.

Friedman, Milton and Meiselman, David. "The Relative Stability of Monetary Velocity and the Investment Multiplier in the United States, 18971958," in Milton Friedman et al., eds., Stabilization Policies. Englewood Cliffs, NJ: Prentice-Hall, 1963.

Friedman, Milton and Schwartz, Anna J. A Monetary History of the United States: 1867-1960. Princeton: Princeton University Press, 1963.

Fry, Maxwell; Julius, Deanne; Mahadeva, Lavan; Roger, Sandra and Sterne, Gabriel. "Key Issues in the Choice of Monetary Policy Framework," in L. Mahadeva and G. Sterne, eds., Monetary Policy Frameworks in a Global Context. London: Routledge, 2000.

Gavin, William T. and Mandal, Rachel J. "Forecasting Inflation and Growth: Do Private Forecasts Match Those of Policymakers?" Federal Reserve Bank of St. Louis Review, May/June 2001, 83(3), pp. 11-19

Gavin William T. and Mandal, Rachel J. "Evaluating FOMC Forecasts." International Journal of Forecasting, 2003, 19(4), pp. 655-67.

Goodfriend, Marvin "Inflation Targeting in the United States?” in Bernanke, B.S. and M. Woodford, The Inflation-Targeting Debate. Chicago: University of Chicago, 2005, pp. 311-37.

Grebler, Leo and Maisel, Sherman J. "Determinants of Residential Construction: A Review of Present Knowledge," in Commission on Money and Credit, Impacts of Monetary Policy. Englewood Cliffs, NJ: Prentice-Hall, 1963, pp. 475-620.

King, Mervyn. "No Money, No Inflation-The Role of Money in the Economy." Bank of England Quarterly Bulletin, Summer 2002, 42(2), pp. 162-77. 
Kohn, Donald L. "Comment," in B.S. Bernanke and M. Woodford, eds., The Inflation-Targeting Debate. Chicago: University of Chicago, 2005, pp. 337-50.

Lacker, Jeffrey M. "Inflation Targeting and the Conduct of Monetary Policy." Presented at the University of Richmond Robins School of Business, March 1, 2005; www.rich.frb.org/media/speeches/ index.cfm/id=70.

Levin, Andrew T.; Natalucci, Fabio N. and Piger, Jeremy M. "The Macroeconomic Effects of Inflation Targeting." Federal Reserve Bank of St. Louis Review, July/August 2004, 86(4), pp. 51-80.

Lindsey, David E.; Orphanides, Athanasios and Rasche, Robert H. "The Reform of October 1979: How It Happened and Why." Federal Reserve Bank of St. Louis Review, March/April 2005, 87(2, Part 2), pp. 187-236.

Liederman, Leonardo and Svensson, Lars E.O. Inflation Targets. London: Centre for Economic Policy Research, 1995.

Loayza, Norman V. and Soto, Raimundo, eds. Inflation Targeting: Design, Performance, Challenges. Series on Central Banking, Analysis, and Economic Policies. Santiago: Central Bank of Chile, 2002.

McCallum, Bennett T. "Price Level Determinacy with an Interest Rate Policy Rule and Rational Expectations." Journal of Monetary Economics, November 1981, 8(3), pp. 319-29.

McCallum, Bennett T. and Nelson, Edward. "Targeting vs. Instrument Rules For Monetary Policy.” Working Paper 2004-011A, Federal Reserve Bank of St. Louis, June 2004.

Meltzer, Allan H. "Monetary and other Explanations of the Start of the Great Depression." Journal of Monetary Economics, November 1976, 2(4), pp. 455-71; reprinted in A.H. Meltzer, Money, Credit and Policy. Northampton: Edward Elgar, 1995, pp. 119-35.

Meltzer, Allan H. A History of the Federal Reserve System, Volume 1: 1913-1951. Chicago: University of Chicago, 2003.
Meyer, Laurence H. "Practical Problems and Obstacles to Inflation Targeting." Federal Reserve Bank of St. Louis Review, July/August 2004, 86(4), pp. 151-60.

Mishkin, Frederic and Schmidt-Hebbel, Klaus. "A Decade of Inflation Targeting in the World," in Inflation Targeting: Design, Performance, Challenges. Series on Central Banking, Analysis, and Economic Policies. Santiago: Central Bank of Chile, 2002, pp. 171-219.

Morande, Felipe. "A Decade of Inflation Targeting in Chile," in Inflation Targeting: Design, Performance, Challenges. Series on Central Banking, Analysis, and Economic Policies. Santiago: Central Bank of Chile, 2002, pp. 583-626.

Orphanides, Athanasios. "Monetary Policy Rules Based on Real-Time Data." American Economic Review, September 2001, 91(4), pp. 964-85.

Orphanides, Athanasios. "Monetary Policy Rules and the Great Inflation." American Economic Review, May 2002, 92(2), pp. 115-20.

Orphanides, Athanasios and van Norden, Simon. "The Unreliability of Output Gap Estimates in Real Time." Review of Economics and Statistics, November 2002, 84(4), pp. 569-83.

Poole, William. "The Role of Anecdotal Information in Fed Policymaking." Presented at Washington University in St. Louis, February 13, 2002; http://stlouisfed.org/news/speeches/2002/ 02 13_02.html.

Poole, William. "FOMC Transparency.” Federal Reserve Bank of St. Louis Review, January/February 2005a, 87(1), pp. 1-9.

Poole, William. "How Should the Fed Communicate?" Presented at Princeton University, April 2, 2005b; http://stlouisfed.org/news/speeches/2005/ 4_02_05.htm.

Radcliffe, G.B.E. "Committee on the Working of the Monetary System: Report.” London: Her Majesty's Stationary Office, August 1959. 


\section{Rasche and Williams}

Reuters News. "Fed's Yellen Says Inflation Target Has Some Merit.” February 11, 2005.

Romer, Christina D. and Romer, David H. "Does Monetary Policy Matter? A New Test in the Spirit of Friedman and Schwartz." NBER Macroeconomics Annual 1989, 1989, pp. 121-70.

Romer, Christina D. and Romer, David H. “A Rehabilitation of Monetary Policy in the 1950s.” American Economic Review, May 2002a, 92(2), pp. 121-27.

Romer, Christina D. and Romer, David H. "The Evolution of Economic Understanding and Postwar Stabilization Policy." Proceedings of the symposium, "Rethinking Stabilization Policy" sponsored by the Federal Reserve Bank of Kansas City, Jackson Hole, Wyoming, August 29-31, 2002b; www.kansascityfed.org/Publicat/Sympos/2002/ sym02prg.htm.

Schreft, Stacey L. “Credit Controls: 1980.” Federal Reserve Bank of Richmond Economic Review, November/December 1990, 76(6), pp. 25-55.

Sargent, Thomas J. and Wallace, Neil. "'Rational' Expectations, the Optimal Monetary Instrument, and the Optimal Money Supply Rule.” Journal of Political Economy, April 1975, 83(2), pp. 241-54.

Sims, Christopher A. "Macroeconomics and Reality." Econometrica, January 1980, 48(1), pp. 1-48.

Sims, Christopher A. “Are Forecasting Models Usable for Policy Analysis?” Federal Reserve Bank of Minneapolis Quarterly Review, Winter 1986, 10, pp. 2-16.

Stock, James H. and Watson, Mark W. "Has the Business Cycle Changed: Evidence and Explanations." Proceedings of the symposium, "Monetary Policy and Uncertainty: Adapting to a
Changing Environment,” sponsored by the Federal Reserve Bank of Kansas City, Jackson Hole, Wyoming, August 28-30, 2003; www.kansascityfed.org/ Publicat/Sympos/2003/pdf/Stockwatson2003.pdf.

Svensson, Lars E.O. “Commentary,” Federal Reserve Bank of St. Louis Review, July/August 2004, 86(4), pp. 161-4.

Svensson, Lars E.O. “Targeting versus Instrument Rules for Monetary Policy: What Is Wrong with McCallum and Nelson?" Federal Reserve Bank of St. Louis Review, September/October 2005, 87(5), pp. 613-25.

Taylor, John B. "Aggregate Dynamics and Staggered Contracts.” Journal of Political Economy, February 1980, 88, pp. 1-23.

Taylor, John B. "Discretion Versus Rules in Practice." Carnegie-Rochester Conference Series on Public Policy, December 1993, 39, pp. 195-214.

Thornton, Daniel T. and Wheelock, David C. "A History of the Asymmetric Policy Directive." Federal Reserve Bank of St. Louis Review, September/October 2000, 82(5), pp. 1-16.

Von Hagen, Juergen. "Hat die Geldmenge ausgedient?" Perspektiven der Wirtschaftspolitik, November 2004, 5(4), pp. 423-53.

Wold, H.O.A. "Causality and Econometrics," Econometrica, April 1954, 22(2), pp. 162-77.

Wold, H.O.A. "A Generalization of Causal Chain Models.” Econometrica, 1960, 28(2), pp. 443-62. 
Rasche and Williams 


\section{APPENDIX}

\section{Characteristics of Inflation-Targeting Regimes of Countries}

\begin{tabular}{lccc} 
Country & Inflation measure & Current target value (\%) & Inflation targets $(\%)$ \\
\hline Australia & Headline CPI & $2-3$ & $2-3$ \\
& & $\begin{array}{c}\text { Treasury underlying CPI } \\
\text { until 1998 and CPI thereafte }\end{array}$
\end{tabular}

$\begin{array}{lr}\text { Brazil } \quad \text { Headline CPI } & 1999: 8 \pm 2 \\ & 2000: 6 \pm 2 \\ & 2001: 4 \pm 2 \\ & 2002: 3.5 \pm 2.5 \\ & 2003: 4 \pm 2.5^{2} \\ & 2004: 4.5 \pm 2.5\end{array}$

$\begin{array}{lll}\text { Canada } & \mathrm{CPI} \text { and core } \mathrm{CPI}^{3} & 2 \pm 1\end{array}$

1991: 3-5 (for 22 months) 1992: 2-4 (multiyear) June 1994: 1.5-3.5 1995-2004: 1-3

$\begin{array}{lll} & \text { Headline CPI } & 2-4\end{array}$
1991: $15-20$
1992: $13-16$
1993: $10-12$
1994: 9-11
1995: 8
1996: 6.5
1997: 5.5
1998: 4.5
1999: 4.3
2000: \pm 3.5

2001 onward: $2-4$

Colombia

CPI

6

1999: 15

2000: 10

2001: 8

2002: 6

2003: 4-6

2004: $5-6$

2005: $4.5-5.5$

2006: $3.5-5.5$

NOTE: ${ }^{1}$ Reserve Bank of Australia (RBA). Although the first formal agreement on the conduct of monetary policy between the RBA and the government was made in 1996, the RBA effectively adopted inflation targeting in 1993. ${ }^{2}$ Bank of Brazil Open Letter 2002, 2003, 2004; www.bcb.gov.br/ingles/relinf/OpenLetter2003.pdf. ${ }^{3}$ Canada's core CPI excludes food, energy, and the effect of indirect taxes. 


\begin{tabular}{|c|c|c|c|}
\hline Adoption date & Who sets the target? & Separate inflation report & Published inflation forecast \\
\hline June $1993^{1}$ & $\begin{array}{l}\text { Government and } \\
\text { central bank jointly }\end{array}$ & $\begin{array}{l}\text { No: statements on } \\
\text { monetary policy } \\
\text { contain prospects for } \\
\text { inflation growth }\end{array}$ & Yes: monetary policy report \\
\hline June 1999 & $\begin{array}{l}\text { Government in consultation } \\
\text { with central bank }\end{array}$ & Yes & Yes \\
\hline February 1991 & $\begin{array}{l}\text { Government and } \\
\text { central bank jointly }\end{array}$ & No & Yes: monetary policy report \\
\hline September 1990 & $\begin{array}{c}\text { Central bank in consultation } \\
\text { with government }\end{array}$ & Yes & Yes \\
\hline September 1999 & $\begin{array}{l}\text { Jointly by government } \\
\text { and central bank }\end{array}$ & Yes & Yes \\
\hline
\end{tabular}




\section{APPENDIX, cont'd}

\section{Characteristics of Inflation-Targeting Regimes of Countries}

\begin{tabular}{lcc} 
Country & Inflation measure & Current targ \\
\hline Czech Republic & $\begin{array}{c}\text { Net inflation } \\
\text { through } 2001^{4} ; \\
\text { headline CPI thereafter }\end{array}$ & $1-3$
\end{tabular}

1-3

Inflation targets (\%)

Net inflation

1998: 5.5-6.5

1999: $4-5$

2000: $3.5-5.5$

2001: 2-4

Headline CPI

band starts Jan. 2002: 3-5;

band ends Dec. 2005: 2-4; from $2006^{5}: 3$

$\begin{array}{llll}\text { Finland }^{6} & \text { Core CPI } & \text { NA } & \text { Since 1993: } 2\end{array}$

\begin{tabular}{|c|c|c|c|}
\hline Hungary & $\mathrm{CPI}$ & $4 \pm 1$ & $\begin{array}{c}\text { 2001: } 7.5 \pm 1 \\
\text { 2002: } 4.5 \pm 1 \\
\text { 2003: } 3.5 \pm 1 \\
\text { 2004: } 3.5 \pm 1 \\
\text { 2005: } 4 \pm 1 \\
\text { 2006: } 3.5 \pm 1\end{array}$ \\
\hline
\end{tabular}

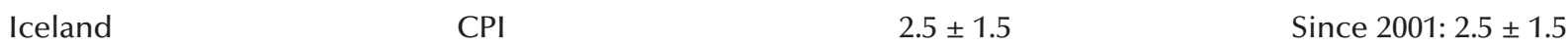

Israel Headline CPI $\quad 1$

$1-3$

992: $14-15$

1993: 10

1994: 8

1995: 8-11

1996: 8-10

1997: $7-10$

1998: 7-10

1999: 4

2000: $3-4$

2001: 3-4

2002: 3-4

2003: $1-3$

2004: 1-3

NOTE: ${ }^{4}$ Net inflation is calculated by the Czech Statistical Office as the growth of prices in the unregulated part of the consumer basket adjusted for changes in indirect taxes and for abolition of subsidies. ${ }^{5}$ The 3 percent inflation target had been announced for the period from January 2006 until the Czech Republic's accession to the euro area. ${ }^{6}$ Since 1998, Finland has been a member of the European System of Central Banks and the Eurosystem. 


\begin{tabular}{|c|c|c|c|}
\hline Adoption date & Who sets the target? & Separate inflation report & Published inflation forecast \\
\hline January 1998 & Central bank & Yes & Yes \\
\hline $\begin{array}{c}\text { February } 1993 \text { to } \\
\text { June } 1998\end{array}$ & Central bank & No & No \\
\hline July 2001 & Central bank & Yes & Yes \\
\hline March 2001 & $\begin{array}{l}\text { Central bank and } \\
\text { government jointly }\end{array}$ & $\begin{array}{l}\text { No: monetary bulletin } \\
\text { contains prospects for } \\
\text { inflation growth }\end{array}$ & Yes \\
\hline December 1991 & Central bank & Yes & Yes \\
\hline
\end{tabular}




\section{APPENDIX, cont'd}

\section{Characteristics of Inflation-Targeting Regimes of Countries}

\begin{tabular}{lcr} 
Country & Inflation measure & Current target \\
\hline Korea & CPI (1998) & $2.5-3.5$ \\
& core inflation (after 1999) &
\end{tabular}

Inflation targets (\%)

core inflation (after 1999)

$$
\begin{aligned}
& \text { 1998: } 9 \pm 1 \\
& \text { 1999: } 3 \pm 1 \\
& \text { 2000: } 2.5 \pm 1 \\
& \text { 2001: } 2.5 \pm 1 \\
& \text { 2002: } 3 \pm 1 \\
& \text { 2003: } 3 \pm 1
\end{aligned}
$$

Jan. 2004: change to mediumterm (instead of annual)

targeting system;

target for 2004-06: 2.5-3.5

$\begin{array}{lr}\text { Mexico } \quad \text { Headline CPI } & 1999: 13 \\ & 2000:<10 \\ & 2001: 6.5 \\ & 2002: 4.5 \\ & 2003: 3 \pm 1\end{array}$

(in line with trading partners)

$\begin{array}{lll}\text { New Zealand } & \text { Headline } \mathrm{CPI}^{7} & 1-3\end{array}$

$1-3$

1990: $3-5$

\begin{tabular}{|c|c|c|c|}
\hline Norway & CPI-ATE $^{8}$ & 2.5 & 2001-present: 2.5 \\
\hline Peru & Headline CPI & $2.5 \pm 1$ & $\begin{array}{c}\text { 1994: } 15-20 \\
\text { 1995: } 9-11 \\
\text { 1996: } 9.5-11.5 \\
\text { 1997: } 8-10 \\
\text { 1998: } 7.5-9 \\
\text { 1999: } 5-6 \\
\text { 2000: 3.5-4 } \\
\text { 2001: } 2.5-3.5 \\
\text { 2002: } 2.5 \pm 1 \\
\text { 2003: } 2.5 \pm 1 \\
\text { 2004: } 2.5 \pm 1\end{array}$ \\
\hline Philippines & $\begin{array}{l}\mathrm{CPI} \text { (they monitor core } \\
\mathrm{CPI} \text { measures also) }\end{array}$ & 4.5-5.5 & $\begin{array}{c}\text { 2002: } 5-6 \\
\text { 2003: } 4.5-5.5 \\
\text { 2004: } 4-5 \\
\text { 2005: } 4-5\end{array}$ \\
\hline
\end{tabular}

1991: $2.5-4.5$

1992: $1.5-3.5$

1993-1996: 0-2

1997-2001: 0-3

2002-present: $1-3$

NOTE: ${ }^{7}$ Officially CPI, but the Reserve Bank of New Zealand targets "underlying" or "core" inflation. (CPI: Since December 1997, the CPI excluding credit services was used; before then, overall CPI was used. In late 1999, mortgage interest rates were removed from the index.) ${ }^{8} \mathrm{CPI}$ inflation adjusted for tax changes and excluding energy products. 


\begin{tabular}{|c|c|c|c|}
\hline Adoption date & Who sets the target? & Separate inflation report & Published inflation forecast \\
\hline April 1998 & $\begin{array}{l}\text { Government in consultation } \\
\text { with central bank }\end{array}$ & Yes & Yes \\
\hline January 1999 & Central bank & Yes & Yes \\
\hline March 1990 & $\begin{array}{l}\text { Government and } \\
\text { central bank jointly }\end{array}$ & Yes & Yes \\
\hline March 2001 & Government & Yes & Yes \\
\hline January 1994 & $\begin{array}{l}\text { Central bank in consultation } \\
\text { with government }\end{array}$ & Yes & Yes \\
\hline
\end{tabular}

January 2002

Jointly by central bank and government 


\section{APPENDIX, cont'd}

\section{Characteristics of Inflation-Targeting Regimes of Countries}

\begin{tabular}{|c|c|c|c|}
\hline Country & Inflation measure & Current target value (\%) & Inflation targets $(\%)$ \\
\hline Poland & Headline CPI & $2.5 \pm 1$ & $\begin{array}{c}\text { 1998: }<9.5 \\
\text { 1999: } 6.6-7.8 \\
\text { 2000: } 5.4-6.8 \\
\text { 2001: }<6-8,3 \text { by } 2003 \\
\text { 2002: } 5 \pm 1,<4 \text { by } 2003 \\
\text { 2003: } 3 \pm 1 \\
\text { 2004: } 2.5 \pm 1\end{array}$ \\
\hline South Africa & $\mathrm{CPIX}^{9}$ & $3-6$ & 2003: 3-6 \\
\hline Spain ${ }^{10}$ & Headline CPI & NA & $\begin{array}{c}\text { 1996: } 3.5-4 \\
\text { 1997: } 2.5 \\
\text { 1998: } 2\end{array}$ \\
\hline Sweden & Headline CPI & $2 \pm 1$ & Since 1995: $2 \pm 1$ \\
\hline Switzerland & Headline CPI & $<2$ & Since $2000:<2$ \\
\hline
\end{tabular}

\begin{tabular}{|c|c|c|c|}
\hline Thailand & $\begin{array}{l}\text { Core CPI (excludes raw } \\
\text { food and energy prices) }\end{array}$ & $0-3.5$ & Since 2000: 0-3.5 \\
\hline United Kingdom & Headline $\mathrm{CPI}^{11}$ & 2 & $\begin{array}{l}\text { 1992: RPIX inflation 1-4 } \\
\text { 1995: "2.5 or less" } \\
\text { 1997: } 2.5\end{array}$ \\
\hline
\end{tabular}

Dec. 2003: CPI inflation $2 \pm 1$

NOTE: ${ }^{9}$ The CPI for metropolitan and other urban areas excluding the interest cost of mortgage bonds. ${ }^{10}$ Since 1998 , Spain is a member of the European System of Central Banks and the Eurosystem. ${ }^{11}$ Since December 2003, CPI inflation became the target, formerly known as the harmonized index of consumer prices. Prior to that, RPIX inflation was targeted.

SOURCE: Authors' compilations based on each central banks' web site discussions on monetary policy, individual monetary policy and inflation reports of each country, Mishkin and Schmidt-Hebbel (2002), and Morande (2002). 


\begin{tabular}{|c|c|c|c|}
\hline Adoption date & Who sets the target? & Separate inflation report & Published inflation forecast \\
\hline October 1998 & Central bank & Yes & Yes \\
\hline February 2000 & $\begin{array}{c}\text { Government after consultation } \\
\text { with the reserve bank and } \\
\text { the national treasury }\end{array}$ & Yes & No \\
\hline $\begin{array}{l}\text { November } 1994 \\
\text { to June } 1998\end{array}$ & Central bank & Yes & Yes \\
\hline January 1993 & Central bank & Yes & Yes \\
\hline January 2000 & Central bank & $\begin{array}{l}\text { No: monetary policy report, } \\
\text { monetary policy assessment, } \\
\text { and inflation forecast } \\
\text { published quarterly }\end{array}$ & Yes \\
\hline May 2000 & $\begin{array}{l}\text { Government in consultation } \\
\text { with central bank }\end{array}$ & Yes & Yes \\
\hline October 1992 & Government & Yes & Yes \\
\hline
\end{tabular}


